\title{
Türkiye’de Modern Banyonun Değişimi: Dergi Reklamları Üzerinden Bir Değerlendirme
}

\author{
The Change of Modern Bathroom in Turkey: An Evaluation through Magazine \\ Advertisements
}

Aysun AYTAÇ ${ }^{1}$, İzmir Yüksek Teknoloji Enstitüsü, Türkiye, aysunaytac@yahoo.com Şebnem TIMUR ÖĞ̈̈T, İstanbul Teknik Üniversitesi, Türkiye, timurseb@itu.edu.tr

\begin{abstract}
Öz: Bu çalışma, Türkiye’de Batılılaşma ile modern banyonun gündelik hayatımıza girişini ve 1980-2012 yılları arasında, tasarım, mimarlık ve dekorasyon dergilerinde yayınlanan banyo reklamlarına bakarak, banyo mekânının geçirdiği değişimi anlamaya çalışır. Çalışma, önce, modern banyonun 19. yüzyıl sonlarında Amerika'da ortaya çıkışını, Amerika'da geçirdiği erken evreleri, dönemin dergi reklamları ve katalog imajları ile destekleyerek kısaca değerlendirir. Sonrasında, Türkiye'de cumhuriyet sonrası modernleşme ve Batılılaşma çabaları ile modern banyonun gündelik hayatımıza girişini, toplumun bu yabancı unsur ile olan etkileşimini aktarır. Son olarak 1980-2012 yılları arasında, onar yıllık dönemler halinde, banyo ve banyo elemanları reklamlarının görselleri eşliğinde, Türkiye'de modern banyonun geçirdiği evreleri yorumlar.
\end{abstract}

\section{Anahtar Kelimeler: Modern banyo, Modernleşme, Reklam görselleri}

Abstract: This study tries to understand the introduction of the modern bathroom into our everyday lives during the Westernisation period in Turkey and also tries to understand the change of the bathroom space by looking the advertisements in design, architecture and decoration magazines between 1980 and 2012. The study, first gives a short account on the appearance of the modern bathroom in the United States through the end of the 19th century and its early phases, supported by images from advertisements and catalogs. Afterwards, it shows the introduction of the modern bathroom into our lives within the efforts of modernisation and Westernisation after the foundation of the Turkish Republic and the interaction between the society and this foreign notion. Lastly, the study tries to read the phases of the modern bathroom and its elements in Turkey via the magazine advertisements through decades between the years 1980-2012.

Keywords: Modern bathroom, Modernism, Advertisements

\section{Modern Banyonun Erken Evreleri}

Modern gündelik hayatımızın temel bir parçası olan banyolar, bugün bildiğimiz haliyle (küvet, duş, klozet, lavabo gibi standart vitrifiye elemanları ve uygun tesisat sistemi), sanayileşme süreçlerine bağlı olarak İngiltere ve Kuzey Amerika'da evlere girmiştir (Giedion 1955; Lupton ve Miller 1992; Wright 1960). ${ }^{2}$ Modern banyonun mekânsal evrimi, sadece sanayileşme ile değil, tesisat ve kanalizasyon sistemlerindeki teknolojik ilerlemeler, değişen toplumsal ve kültürel pratikler ve normlarla da ilişkili olmuştur (Giedion 1955; Lupton ve Miller 1992). Modern banyodan önceki banyo pratikleri iyileşme ve hastalıklardan kurtulma amaçlı yenilenme fikrine odaklanırken 19. yüzyılın ikinci yarısından itibaren, temizlik fikri, banyo pratiklerini belirlemeye başlamıştır. 19. yüzyıl boyunca, banyo, morfolojik olarak buhar banyosundan duş banyolarına, sıcak hava banyolarından özel kübiklere kadar birçok değişim göstermiştir (Giedion 1955). 1900'lü yıllarda, tesisat ve kanalizasyon sistemleri sayesinde, küvet ve duştan oluşan seyyar banyolar, endüstriyel vitrifiye elemanları ile sabit bir mekân ve pozisyona dönüşerek evlere girmiştir. Modernleşmenin öncü

\footnotetext{
${ }^{1}$ Bu çalışmanın bir kısmı, yazarın, İstanbul Teknik Üniversitesi'nde devam eden doktora çalışmasına dayanmaktadır. Yazar katkılarından dolayı Dr. Nilüfer Talu'ya teșekkür eder.

${ }^{2}$ Yıkanmanın ve banyonun tarihçesi bu çalışmanın kapsamı dışındadır, banyonun tarihi ile ilgili kaynaklar için bkz.:

Wright 1960; temizlenme mekânlarına tarihsel bir perspektiften bakan kapsamlı bir yıkanma ve banyo mekânı tarihi.

Giedion 1955; bir bölümünün tamamen antik çağlardan 20. yüzyıla kadar yıkanmanın ve banyonun evrimine ve tarihine ayrıldığı, makineleşmenin ve modernliğin tarihi.

Hembry 1990; kaplıcaların tedavi edici ve toplumsal yönlerine odaklanan, İngiltere'de 1560-1815 yılları arasında banyo yapma tesislerinin toplumsal tarihi.

Lupton ve Miller 1992; eleştirel ve feminist bir bakışla ve maddi kültür çalışması yaklaşımıyla, Amerika'da 1890-1940 yılları arasında banyonun ve mutfağın sağlık ve temsil anlamında evrimi.

Shove 2003; temizlik kavramının banyo mekânı ile ilişkilendirildiği, banyo yapma ve duş alma pratiklerinin nasıl gündelik hayatımızın 'normal' bir parçası haline geldiğinin sorgulandığı, hijyen ve temizliğin tarihçesi.

Vigarello 1988; orta çağdan başlayarak 20. yüzyıla kadar, Fransa'da temizlenmenin ve beden bakımının kültürel ve tarihsel bir dökümü.
} 
tarihçilerinden Sigfried Giedion (1955), sabit banyonun (the fixed bathroom) ${ }^{3}$ bu değişim sürecini "göçebelikten sabit koşullara" geçiş olarak tanımlar (s. 682).

İngiltere'de 1880-1910 yılları arasında, orta sınıfın dahi kullandığı, pencereli, ferah ve yüksek kalite vitrifiye elemanları içeren şatafatlı bir mekân olan 'sabit banyo' (Giedion 1955; Wright 1960) büyük boy halıları, desenli duvar kağıdı ve vitray camları ile varlık ve zevkin sembolü haline gelmiştir (Wright 1960) (Resim 1). Amerika'da ise sabit banyo, evlerden önce otellerde kendisini göstermiştir. Ancak, otel banyosunun da gerçek anlamda yaygın hale gelmesi, 1908 yılında, Buffalo'da yeni açılan bir otelin 'bir yatak ve banyo, bir buçuk dolara' sloganı ${ }^{4}$ ile olmuştur (Giedion 1955) (Resim 2a). Bu şekilde, banyonun düşük bir maliyet ile her odaya uygulanabileceği ispatlanmış ve bu da standart Amerikan planı olarak sonuçlanan, banyoyu apartman planlarına dahil etme eğilimini ortaya çıkarmıştır. Artık, banyo, sıkıştırılmış donatılı bir hücre olarak yatak odasının uzantısıdır.

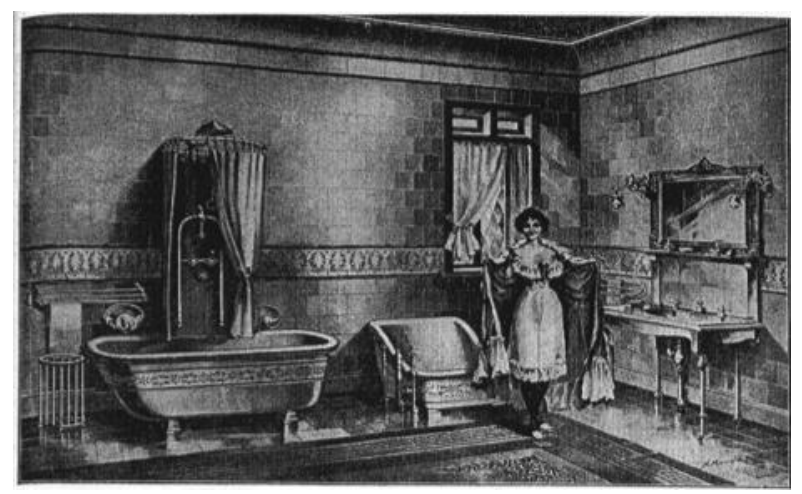

Resim 1: Banyo kataloğundan bir sayfa, İngiltere, 1901 (Giedion 1955, 687).
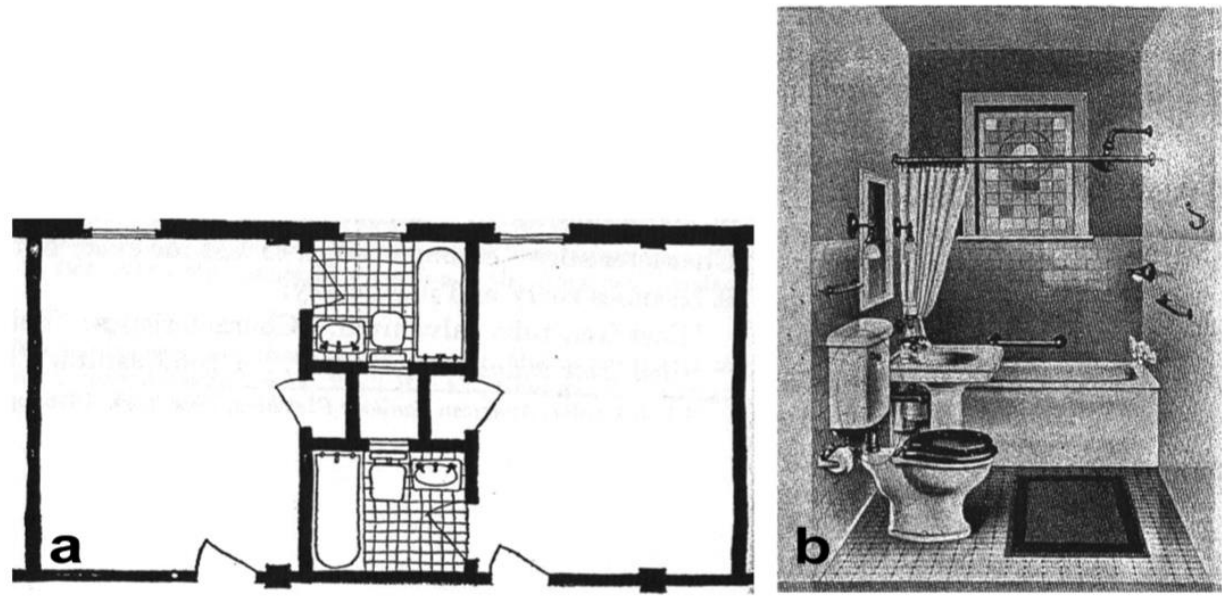

Resim 2: a) Buffalo'daki Statler Hotel'in ortak havalandırma ve tesisat şaftıyla planlanmış sıkıştırılmış banyolu iki odası (the compact bathroom), 1908 b) Amerikan sıkıştırılmış banyosu (the compact bathroom), 1915 (Giedion 1955, 698-99).

Resim 2b'deki, 1915 yılına ait, değişmeyen planı gösterilen sıkıştırılmış Amerikan banyosu (the compact bathroom), İngiliz banyolarından farklı olarak, olabildiğince dar mekânlara sı̆ğırılmaya ve vitrifiye elemanları bir duvar boyunca sıralanmaya çalışılmıştır. Seri üretim teknikleri ile üretim maliyetleri azaltılarak küvet daha geniş kitlelere ulaştırılmıştır (Giedion 1955, Glassberg 1979). Seri üretim ile üretilen, tek parça, çift kabuklu, gömme, beyaz küvet, o dönemin banyo mekânlarının tasarımını ve boyutlarını belirlemeye başlamıştır. ${ }^{5}$ 1920'lere gelindiğinde, gömme küvet, Amerikan banyosunun modülü ve standardı olarak, banyonun belkemiği ve dolayısıyla sembolü haline gelmiştir (Giedion 1955, Winkler ve Fisher 1989). Amerikan banyosunda boyutlar küvete göre belirlenirken, İngiliz

\footnotetext{
${ }^{3}$ Seyyar banyonun sabit bir mekâna dönüşmesinde vitrifiye elemanlarının sabitlenmesi en önemli etken olmuştur. Bu yüzdendir ki sabit banyo-the fixed bathroom adını vitrifiye elemanlarından-fixtures'dan almıştır.

4 Orijinal slogan; 'A bed and a bath for a dollar and a half' (Giedion 1955, 698).

5 20. yüzyılın başlarında çeşitli firmalara ait banyo tasarımları ve planlarını içeren bir derleme için bkz. Winkler ve Fisher 1989.
} 
banyolarında, ısınma maliyetini azaltmak amacıyla banyo boyutları küçük tutulmaya çalışılmıştır (Rybczynski 1987). Büyük veya küçük, kullanışlı bir banyo, 20. yüzyılın modernist mimarları tarafından, elektrikli ütü, çamaşır makinesi ve merkezi 1sıtma sisteminin yanı sıra, bir evi ‘modern' yapan unsurlardan biri olarak tanımlanmıştır (Rybczynski 1987).

'Modern' evin 'modern' banyosu, iç mekân tasarımları açısından ülkelere göre farklılık göstermiştir. Amerika'da banyo beyaz ve sade bir tasarımla ortaya çıkıp ilk yıllarda bundan ödün vermezken, İngiltere'de banyo tasarımlarında ve vitrifiye elemanlarında çoğunlukla ağır ve ayrıntılı dekorlar kullanılmıştır (Wright 1960). Örneğin, 19. yüzyıl sonunda, katı modernist Adolf Loos (1898), mekânın temizliğine işaret eden beyaz rengi, banyo için tek uygun renk olarak vurgulamıştır. Avusturya banyolarının iç mekân tasarımını, vitrifiye elemanlarını ve tesisat sistemini Amerika'dakilere göre kalitesiz olmalarıyla eleştiren Loos, beyaz olması gerekirken koyu renk olan vitrifiye elemanlarını ve renkli duvar karolarını eleştirmiştir.

Banyo pratiğinin, hastalıklardan kurtulma ve iyileştirme ile ilişkilendirildiği ilk dönemlerinin aksine, modern banyonun ilk 20 yılı hijyen idealine fazlasıyla odaklanmıştır (Lupton ve Miller 1992). Modern banyo, özellikle Amerika'da, bu ideali, malzeme, detay ve renk gibi unsurlarla yansıtmıştır. Lupton ve Miller'a göre (1992), bu ülküyü beslemede önemli bir yeri olan Amerikan katalogları ve reklamları, toz ve mikropları barındırmayan yekpare duvar yüzeylerini, mobilya yerine vitrifiye elemanlarını, oyma detaylar ve Viktoryen objelerin abartılı dekorları yerine, porselen sırlı endüstriyel donatıların kullanımını teşvik etmiştir. Tüm bunların yanında, renk olarak 'hastane beyazı' banyo sağlığın korunmasının birinci koşulu olmuştur (Lupton ve Miller 1992). Banyo mekânında öne çıkan hijyen eğiliminin yanı sıra, bedensel hijyen için pazarlanan ürünler de kitlesel dağıtımı ve tüketimi teşvik eden ambalaj sektörü ile artmıştır (Resim 3).

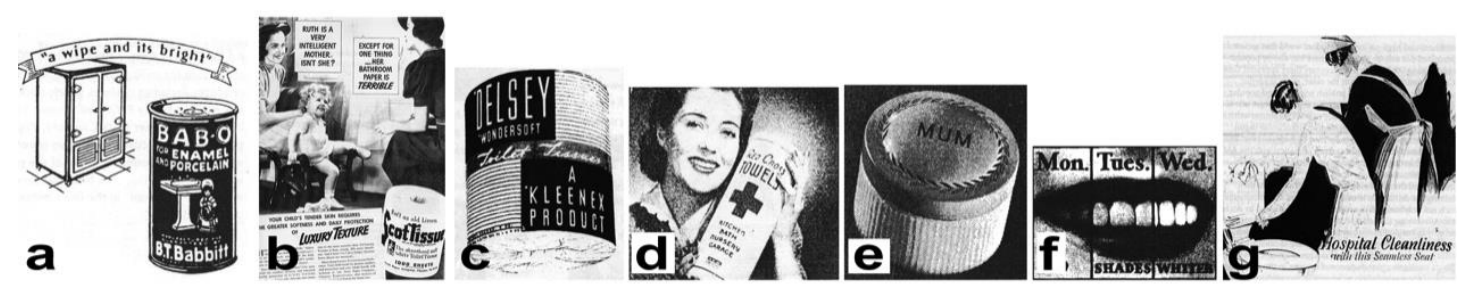

Resim 3: 20. yüzyılın başlarında hijyen için pazarlanan çeşitli ürünlerin reklamları. a) Emaye ve porselen kaplamalar için kullan-at mendil b) Scottissue tuvalet kağıdı c) Kleenex tuvalet kağıdı d) Red Cross kağıt havlu e) Mum koltuk altı ter önleyici f) Diş beyazlatıcı g) 'Hastane Temizliği' sağlayan yekpare (seamless) klozet kapağı (Lupton ve Miller 1992).

1930'larda, Amerika'da, dönemin hakim tasarım stili 'streamlining ${ }^{6}$, evlerden sonra banyoların ve mutfakların iç mekân tasarımlarını da etkilemiştir (Lupton ve Miller 1992) (Resim 4). Bu stil, temizliği kolay ve mikrop barındırmayan çıkıntısız yüzeyleri ve yuvarlatılmış kenarları ile öne çıkmış ve banyoda hijyen ideali bir kere daha desteklenmiştir.

Banyoda beyazın egemen olduğu yılların ardından, 1930'larda, renkli yüzeylerin ve vitrifiye elemanlarının ortaya çıkmasıyla beraber, banyoda hijyenden sonra, dekorasyon da öne çıkmaya başlamıştır. Başlarda renkli banyoda hakim renk pembe olmuş, devamında ise, mavi-yeşil banyolar pembeyi takip etmiştir, ancak renkli banyonun zirveye ulaşması 1950'li yılları bulmuştur (Resim 5). Lupton ve Miller (1992), renkli banyonun geç yaygınlaşmasının sebebini yüksek maliyetlere ve beyaz rengin hijyen ideali ile örtüşen güçlü imajına bağlamıştır. 1950'li yılların renkli banyo reklamlarında göze çarpan bir eleman da renkli kare ya da köşe küvetler olmuştur (Resim 5c, 5d).

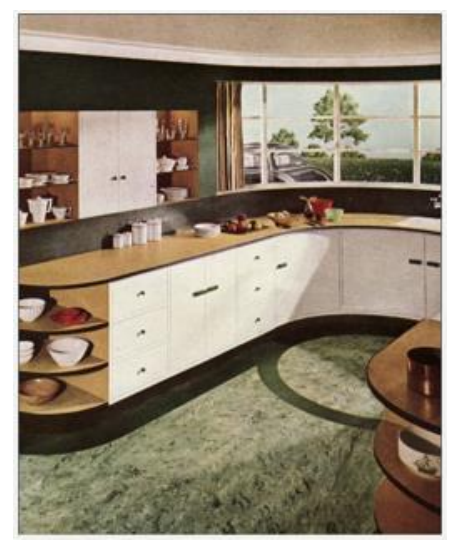

Resim 4: 1937 Better Homes \& Gardens dergisinden streamlining akımından etkilenmiş bir mutfak tasarımı (www.antiquehomestyle.com).

\footnotetext{
${ }^{6}$ Aerodinamik olarak daha az hava direnci sağlayacak hava ve kara taşıtlarının tasarımlarında uygulanan, su damlası formundan esinlenen 'streamlining' stili, o dönem, hem taşıtlara hem de taşıtlarla ilgisi olmayan ürünlere uygulanmıştır.
} 

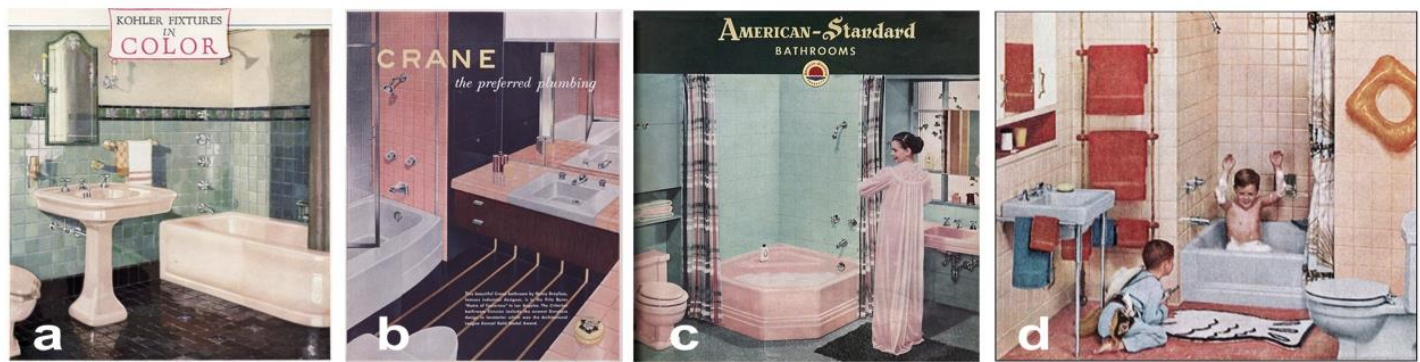

Resim 5: Amerika'daki çeşitli dergilerden renkli banyo reklamları. a) Kohler 1928 b) Henry Dreyfuss tasarımı Crane 1951 c) American-Standard 1953 d) American-Standard 1957

(www.flickr.com and www.midcenturyhomestyle.com).

Amerika'da sıkıştırılmış banyonun yaygınlaşmasından sonra, Amerika, banyo mekânının boyutları üzerine tekrar düşünmeye başlamış, asgari boyutlardaki standart banyonun yanı sıra, daha büyük banyo tasarımları ortaya çıkmıştır. Bu büyük banyolar, lüks ve evliliğin mahrem zevkleri ile ilişkilendirilmiştir. Ayrıca, tuvalet ve banyo ilişkisi tartışılmış ve sonuç olarak bir kapı ile tuvaleti banyodan ayıran tasarım önerileri geliştirilmiştir (Resim 6). Bunu yanı sıra, banyo boyutlarının büyümesi, sınıf farkı ile de ilişkilendirilmiş, evde çalışan yardımcıların banyosu küçülürken, ev sahibinin banyosu büyümüştür. Sonuç olarak, 1950'li yıllarda oluşan çeşitli tasarım fikirleri, birden fazla girişi olan banyolar (Resim 6b), misafirler için lavabo (powder room), her yatak odasına ayrı banyo ve ebeveyn banyosu gibi banyo tasarımları olarak çeşitlenmiştir (Lupton ve Miller 1992).
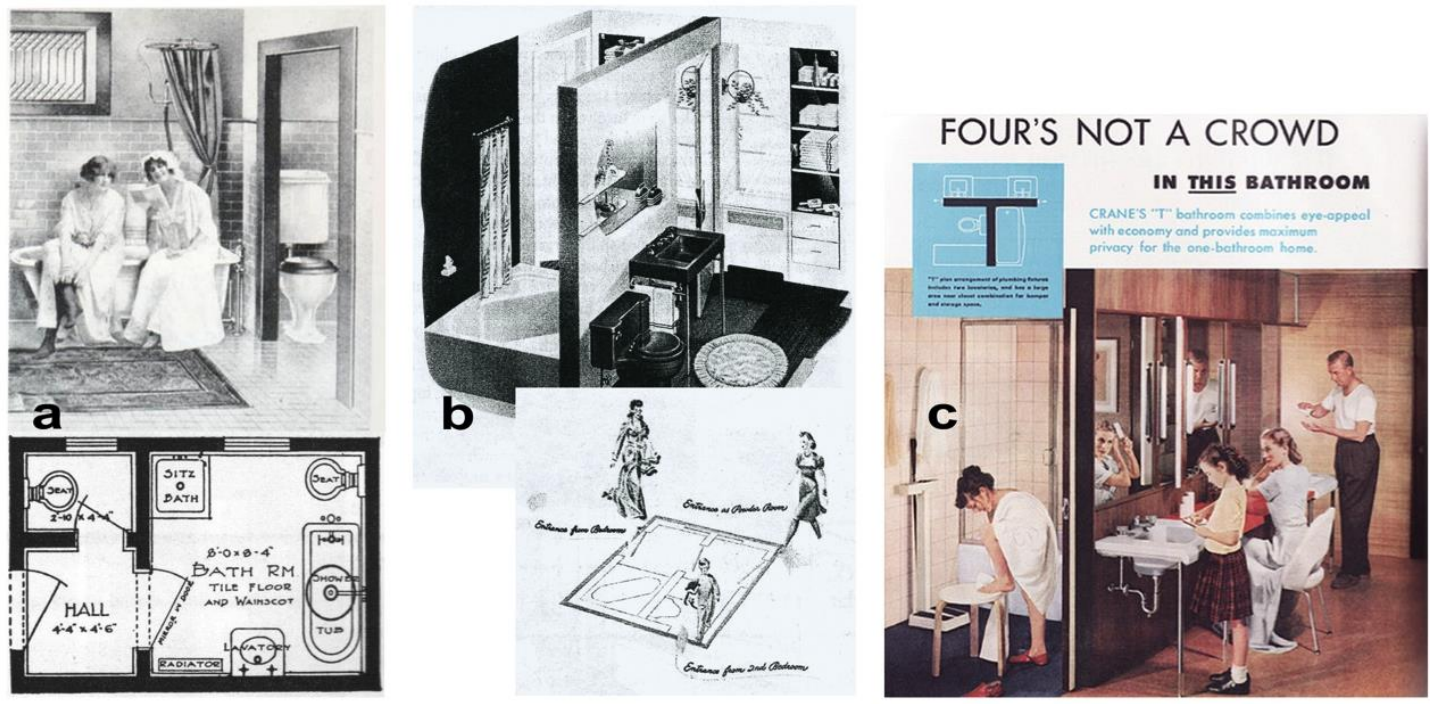

Resim 6: Çeşitli bölünmüş banyo planları ve reklamları. a) Standard Sanitary Mfg. Co. firmasının tuvaleti banyodan bir kapı ile ayırdığı reklamı (1912) ve tuvaletin banyodan tamamen ayrıldığı bir plan (1917)

b) Standard Sanitary Mfg. Co. firmasının Duo-Use banyosu ve çoklu kullanımının şeması (1944)

c) Crane Bathroom firmasının T planı aracılığıyla tek banyo hacminde mahremiyete izin veren tasarımı (1952) (Lupton ve Miller 1992, 36-37 ve www.flickr.com).

Modern banyo için tüm bu form, renk ve boyut arayışları sürerken, fazlasıyla endüstriyel ve tamamen 'modern' olan banyonun, aslında, beden hareketlerinin fonksiyonel gerekliliklerine uygun olarak tasarlanmadığı ortaya çıkmıştır. 1966 yılında, Alexander Kira, 50'li yılların sonlarına doğru banyo ergonomisi hakkında yaptığı detaylı araştırmasını, bugün klasikleşmiş olan, 'The Bathroom: Criteria for Design' (Banyo: Tasarım için Kriterler) başlıklı kitabında yayınlamıştır. Kira'nın bu önemli araştırması, "kişisel hijyenin araştırılmamış problemleri ve aktivitelere uygun ortamların tasarımı için temel kriterlerin ve etkenlerin tespit edilmesi” (s. iii) gibi konuları içermektedir. ${ }^{7}$

\footnotetext{
${ }^{7}$ Alexander Kira'nın bu çalışması, akademik literatürde, temel işlevsel bir yaklaşımla beraber banyonun kullanımını toplumsal açılardan yorumlayan ilk çalışma olarak kabul edilir. Çalışma, banyo mekânının ve elemanlarının nasıl kullanıldığına dair detaylı bir döküm niteliğindedir. Kira,

kullanıcıları, ızgara bir arka plan önünde, ellerini, yüzlerini, saçlarını, tüm bedenlerini yıkarken, idrar yaparken veya dışkılama sırasında fotoğraflama
} 
1960’lı yıllara gelindiğinde, reklamlarda, banyoda renk kullanımının devam ettiği, pembe, mavi ve yeşil vitrifiye elemanlarının kullanımının da yaygınlaştığı görülmektedir (Resim 7a, 7b). Bu yıllarda, renkli ve desenli tuvalet kağıdı ve kağıt havlu reklamları da dikkat çekmektedir (Resim 7c). Bu dönemde, teknolojideki ilerlemeler ile birlikte, otomatik çamaşır ve kurutma makinesi reklamları da artmış, onları deterjan ve yumuşatıcı reklamları takip etmiştir (Resim 7d). Tuvalet tasarımındaki yenilikler de reklamlara yansımıştır. Duvara asılı tuvalet reklamları banyo temizliğini kolaylaştırdığı iddiası taşırken (Resim 7e), yeni sifon teknolojisi ile tuvaletler daha sessizleşmiştir. Ayrıca, 60’ların sonuna doğru, laminant paneller banyolarda renkli karoların yerini almıştır (Resim 7f). ${ }^{8}$
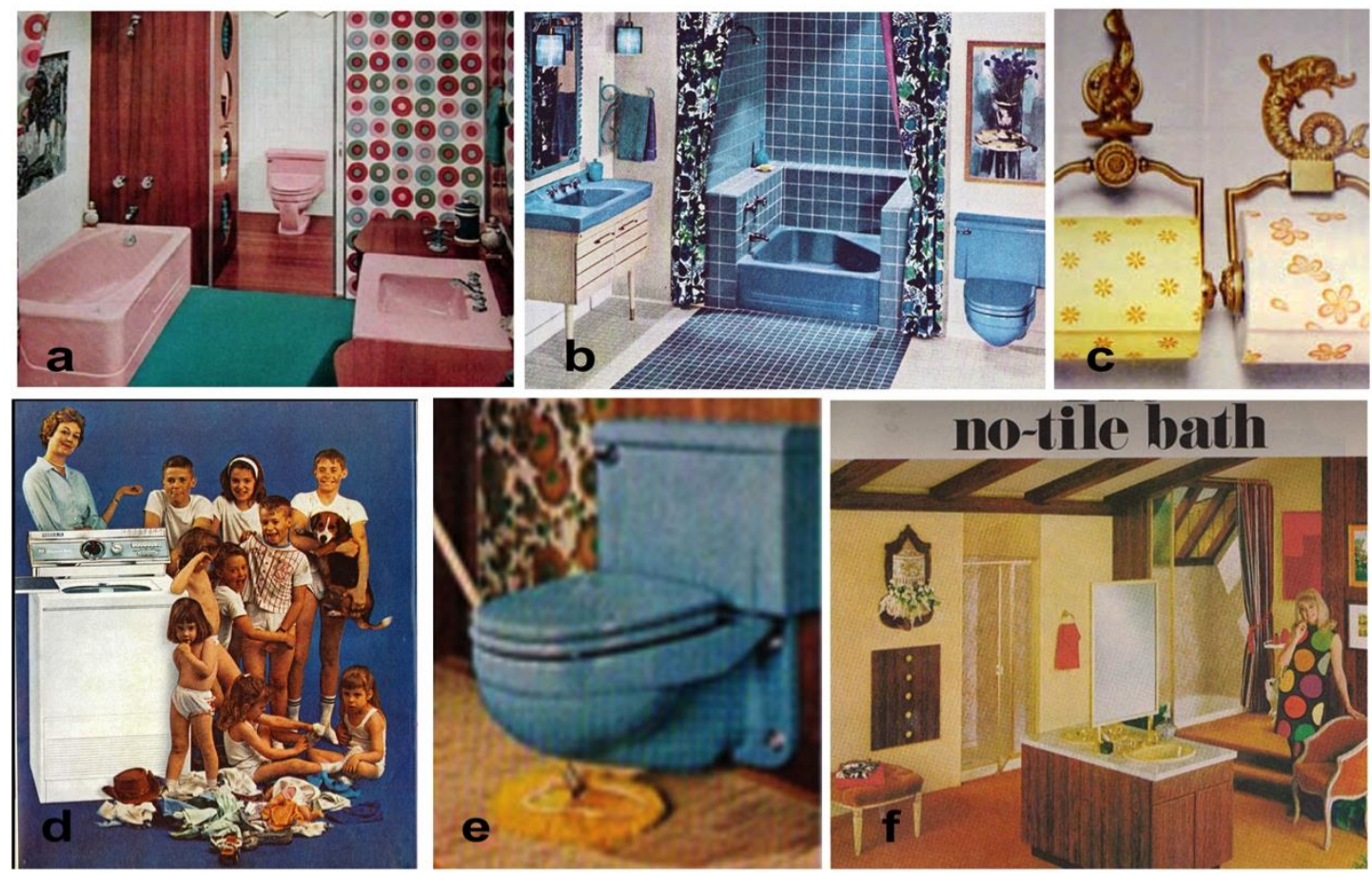

Resim 7: 60’lı yıllara ait çeşitli reklamlar. a) 1960 American Standard b) 1961 American Standard c) 1966 Lady Scott renkli ve desenli tuvalet kağıdı d) 1960 Borg-Warner Çamaşır Makinası e) 1961 American Standard asma klozet f) 1969 Formica Laminant reklamı (adclassix.com, vintage-ads.com, midcenturyhomestyle.com, flickr.com).

\section{Türkiye’de Batılılaşma ve 'Modern' Banyonun Ortaya Çıkışı}

Modern banyo, 20. yüzyılın ilk yarısı boyunca Avrupa'da ve Amerika'da sabitlenmiş vitrifiye elemanları ile 'sabit' ve 'standart' bir mekân haline gelirken, Türkiye'de de, 1923 yılında cumhuriyetin kurulmasının ardından, yavaş da olsa yaygınlaşmaya başlamıştır. Bu dönemlerde banyo, Batılılaşma ve modernleşmenin bir vasıtası olarak temsil edilmiş ve algılanmıştır (Gürel 2008). Meltem Ö. Gürel'in (2008), modern banyoyu, onun vitrifiye elemanlarını ve pratiklerini, Türkiye'nin Batılılaşma süreci dahilinde, tarihsel olarak analiz ettiği çalışmasında, banyo küresel modernliğin bir ürünü olarak gösterilmiştir. Gürel'e (2008) göre, Türkiye'de modern banyo tarihi, modernliğin ikilemini temsil etmektedir; modernlik "eskiyi, gelenekseli, tanıdık olanı ve kendinde var olanı yıkmayı, ayrıca yeniyi, ilericiyi, güncel olanı ve yabancı olanın tanıtımını kapsar" (s. 216).

Türkiye'de modern banyodan önce, temel ihtiyaçlar, alaturka tuvalet, hamam ve gusülhane ile giderilmekteydi. Alaturka tuvalet geleneksel olarak, evlerin bahçesinde veya avlusunda yer almaktaydı (günümüzün alaturka tuvaletleri hala Türkiye'de, Orta Doğu'da ve Asya'da bir çok kullanıcı tarafından tercih edilmektedir). Yıkanmak için ise halk, kamusal yıkanma mekânı olan hamamları kullanmaktaydı. Hamam sadece temizlik için gidilen bir mekân olmayıp tüm mahalle tarafından kullanılır, özellikle kadınlar için önemli bir sosyalleşme aracı haline gelirdi. Hamamların yanı sıra, bazı evlerde, yatak odalarında bir dolap gibi görünen, açıldığında içinde su kapları ve su gideri bulunan, çiftlerin cinsel ilişki sonrası, İslam dininin gerekliliklerine göre yıkanmalarına (abdest almalarına) olanak veren gusülhaneler bulunmaktaydi.

1923 yılında, Türkiye Cumhuriyeti'nin kurulması ile beraber ülkenin sosyal, politik, kültürel ve ekonomik yapısını değiştirmeye yönelik devrimler de başlamıştır. Cumhuriyetin, Osmanlı İmparatorluğu'nun şarkiyatçı temsillerini terk

yöntemi ile, banyoyu ve elemanlarını ve onların işlevlerini analiz etmiştir. Gerekli ayarlamalar ve düzenlerle birlikte uygun tasarım çözümleri de önererek literatürde büyük bir boşluğu doldurmuştur.

${ }^{8}$ Formica markası adı altında üretilen bu paneller, daha sonra Türkiye'de malzemenin adıyla değil 'formika' olarak anılacaktır. 
ederek, Batılı modellere göre yeni bir ulus yaratma amacı, gündelik hayata, mimari ve tasarım kültürlerine de yansımaya başlamıştır (Bozdoğan 2002, Gürel 2008). Sibel Bozdoğan (2002), erken cumhuriyet döneminde Türk mimarisinin kültürel tarihini anlattığı 'Modernizm ve Ulusun İnşası' kitabının 'Modern Yaşam-Kübik Evler ve Apartmanlar' adlı bölümünde, modern banyonun ve elemanlarının, idealleştirilmiş modern ev ve apartman planlarına girişini de aktarır. İlk Batılı tarzda banyo vitrifiye elemanları 1920'lerde ve 1930'larda, mimarların ev planlarında görülmeye başlamıştır. O dönemlerin mimari yayınlarında ve popüler dergilerinde yayınlanan örnek evler, Batılı tarzdaki hayatları sergilemektedir. Ancak, yabancı yayınlardan değiştirilmeden alınan bu ev planları, Türkiye'deki orta sınıf için tamamen yabancı bir yaşam tarzı sunmaktadır. 1936 yılından itibaren, ülkenin önde gelen cumhuriyet mimarları yumuşak geçişlerle, geleneksel öğeleri de içeren, daha az 'yabancı' ev planları önermeye başlarlar; bu planlarda 'standart' banyonun yanında (Batılı tarzda klozet ve küvet), ondan ayrı olarak alaturka tuvalet de yer alır (Bozdoğan 2002).

Başkent Ankara'da, Mimar Kemalettin Bey’in tasarladığı, 1928 yılında inşa edilen ve dönemin toplu konut örneği haline gelen İkinci Vakıf Apartmanı'nda merkezi 1sıtma, elektrik ve asansör bulunmaktaydı. Tüm bu özellikleri ile yüksek standart olarak değerlendirilen İkinci Vakıf Apartmanı daireleri, 'modern' banyo ve vitrifiye elemanlarını da içermekteydi ve bu da, o dönemde, 'banyo yüksek standarttır' görüşünü vurgulamıştır (Yavuz ve Özkan 2005). 20. yüzyılın ilk yarısı boyunca apartmanların yaygınlaşması ile banyo da kentlerde yaygınlaşmaya başlamıştır. Bu yüzyıl boyunca, banyo, apartman yaşamı ile beraber evrimleşerek Batının ve modern yaşamın simgeleri haline gelmiştir, öte yandan, geleneksel tuvalet pratiklerini geride bırakamayan kullanıcılar için alaturka tuvaletler çoğu apartman planında yer almaya devam etmiş ve ilerleyen yıllarda, banyolar yenilenirken, çoğu alaturka tuvalet klozete dönüştürülmüştür (Gürel 2008, Tasarımcı Gözüyle 1990). Gürel'e göre (2008), özellikle 20. yüzyılın ikinci yarısında, alaturka tuvalet, bir çok kullanıcı tarafından tercih edilirken, bir kısım tarafından da geri kalmışıı̆ı̆n, az gelişmişliğin ve gayrisıhhi koşulların simgesi ve geçmişin, kırsal geleneklerin, pisliğin ve alt tabakanın bir ifadesi olarak algılanmıştır.

Klozetin yanı sıra, banyonun 'modern' elemanlarından bir diğeri olan küvet de, modern banyonun yaygınlaşmasıyla statünün ve Batılılaşmanın sembolü haline gelmiştir. Ancak, kültürel alışkanlıklar ve dini inançlara göre durgun suda yıkanmayan toplum, küvet ve küvete ait pratikleri yabancı olarak algılamıştır. Hamamdan beri alışılagelmiş olan akan su ile yıkanma alışkanlığına tezat bir nesne olarak banyolarda 1.5 metrekare yer kaplayan küvet, bir nevi duş teknesi olarak kullanılmıştır (Bektaş 1998, Gürel 2008). ${ }^{9}$ Küveti içselleştirmeye çalıșan toplum, su kesintilerinde faydalanmak için küvete su doldurmak, büyük ev eşyalarını küvette yıkamak, perde, halı veya battaniyeleri küvette suya bastırmak gibi küvet ile ilgili yeni kullanımlar icat etmiştir. Küvetin işlevi dışında kullanılmasına karşın, dönemin tanınmış mimarlarından Nejat Ersin'e göre, 1950'lerde Ankara'da, küvete talep yüksek olmuştur, ancak ithal edildiğinden bulması zor ve dolayısı ile pahalı bir ürün haline gelmiştir (Gürel 2008). Gürel'in Ersin ile yaptığı röportajda (2008), Ersin, küvete olan talebi fark ettiğini, geleneksel yıkanma biçimlerimizi çalışarak (oturarak ve bir kaptan tas ile su dökünme) siyah mermerden, oturmalı bir küvet tasarladığını söylemiştir (Resim 8a). Toplumun hamamdan gelen geleneksel yıkanma alışkanlıklarına yakın olan bu tasarım, duş başlığı ile beraber aranan bir ürün olmuş ve bir çok yapıda standart küvetin yerine tercih edilmiştir (Gürel 2008). Modern banyo ile beraber gelen küvetin toplum tarafından rahat bir şekilde kullanılamadığ ${ }_{1}^{10}$ geribildirimini alan ve Anadolu'da kullanıcıların evlerine mermer kurna koydurttuklarını öğrenen seramik sağlık gereçleri üreticisi Serel firması da, 1980'lerin sonuna doğru, küvete seçenek olarak seramik kurna tasarlamış ve piyasaya sürmüştür (Tasarımcı Gözüyle 1990) (Resim 8b).
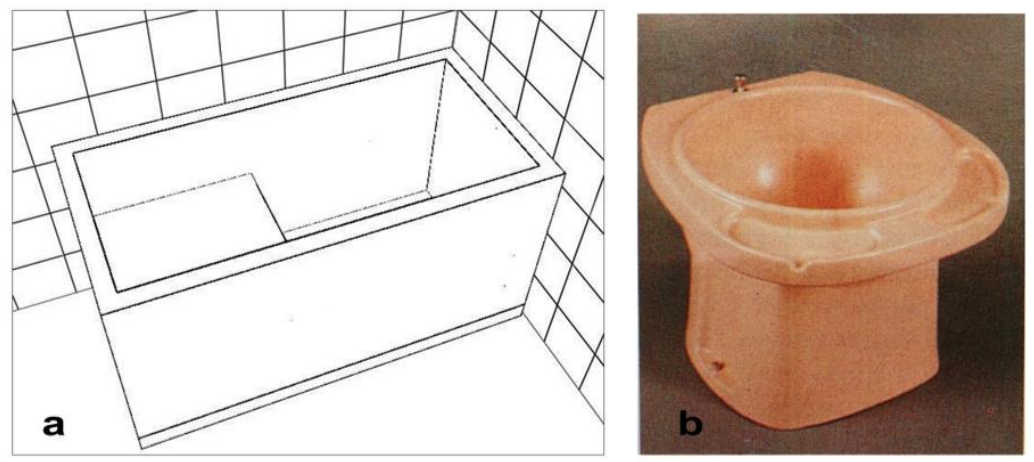

Resim 8: a) Mimar Nejat Ersin tarafından, Türkiye'deki kullanıcıların yıkanma ihtiyaç ve alışkanlıklarına göre tasarlanmış, duş ünitesi ve oturma yeri olan mermer küvet (temsili küvet çizimi Güler (2008, s. 227) tarafından çekilen fotoğraftan yazar tarafından oluşturulmuştur) b) Serel Seramik tarafindan 80'lerin sonuna doğru piyasaya sürülen seramik kurna (Arredamento Dekorasyon Banyo'91, 1990, s. 165).

\footnotetext{
${ }^{9}$ Küvetin konut maliyetini nasıl yükselttiği, varlığın sembolü haline nasıl geldiği ve hayat tarzlarımıza ne kadar yabancı olduğu hakkında kısa makale için bkz. Bektaş 1998.

${ }^{10}$ Küvetin içine plastik bir tabure ve kova koyularak yıkanılması ve su dökmek için tas benzeri şeyler kullanılması.
} 
Batılılaşma ile apartmanlara ve evlere giren 'modern' banyonun bir başka yabancı elemanı da bide olmuştur. Bide ilk olarak, cinsel ilişki sonrası genital bölgelerin temizlenmesi amaçlı Fransa'da kullanılmaya başlanmıştır (Rybczynski 1987). Türkiye'de ise, varlığın ve modernizmin sembolü olarak algılanan ve klozet ile beraber set halinde satılan bide, banyolarda 1950-1970 arasında varlık gösterebilmiştir (Gürel 2008). Takip eden yıllarda, hem banyoda çok yer kapladığı hem de klozetlerde taharet musluğu bulunduğu için bideye olan rağbet azalmıştır. Banyoda, halihazırda bide varsa, ayak yıkamayı pratikleştirdiği için çoğunlukla ayak yıkamak için kullanılmıştır. 1990 yılında gerçekleştirilen bir röportajında, Serel firmasının tasarımcısı, Türkiye'de bidenin hiçbir zaman tam anlamıyla popüler olmadığını, 10 setten bir veya ikisini bide ile sattıklarını ifade etmiştir (Tasarımcı Gözüyle 1990).

\section{80'lerden Günümüze Türkiye'de Banyonun Evreleri}

Ülkemizde modern banyo, ilk ortaya çıkışından bugüne kadar bir çok açıdan değişiklik göstermiştir. Hala süregiden bu değişim, ekonomik değişiklikler, toplumsal ve kültürel değişiklikler ve teknolojik ilerlemeler gibi farklı değişkenlerden etkilenmektedir. Bu bölümde, söz konusu değişim, tasarım, mimarlık ve dekorasyon dergilerindeki banyo ve banyo elemanları reklamları üzerinden aktarılmaya çalışılmıştır. ${ }^{11}$ Reklamlar, hem dergi yayıncılığı sektörünün hem de seramik sağlık gereçleri sektörünün gelişmeye başladığı 1980'lerden ${ }^{12} 2012$ yılına kadar olan aralıktan seçilmiş ve görsel olarak değerlendirilmiştir. Reklamlarda sergilenen ürünler renk, malzeme, form gibi temel tasarım unsurları açısından değerlendirilirken bağlamı dahilinde zaman zaman işaret ettikleri hayat tarzları açısından da ele alınmıştır.

\section{0'ler}

1980'lerde, liberal ekonomiye geçiş ve ülkedeki serbest pazar, seramik sağlık gereçleri sektörünün gelişimi banyo vitrifiye elemanlarında ve aksesuarlarında çeşitliliğin artmasına olanak vermiştir. Özellikle dönemin ikinci yarısında, vitrifiye elemanlarındaki renk çeşitliliği, desenli duvar karoları ve aksesuarlar reklamlarda öne çıkmaktadır (Resim 9a, 9b, 9d, 9f). Bu çeşitlilik, aynı yıl içinde birbirine zıt tasarım eğilimlerinin gözlemlenebildiği, birbirinden çok farklı tasarımların olduğu bir pazar da sağlamaktadır. Bir reklamda ağır süslemeli vitrifiye tasarımları sunulurken başka bir reklamda basit ve geometrik çizgilerden oluşan bir model sergilenebilmektedir (Resim 9e, 9g). Ayrıca, ithalatın serbest kalması ile beraber yurt dışı menşeili firmaların reklamları da yerel firmalarla beraber dergilerde yaygınlaşmaya başlamıştır (Resim 9c). Buna bağlı olarak, su jetli küvet reklamlarının ve sauna tipi duş kabini reklamlarının arttığı gözlemlenmektedir. Yerel firmalar tarafından da üretilen duş kabinleri, hijyen ve kullanım kolaylığı açısından, o döneme kadar kullanılan ve hatta daha sonra da kullanımı devam eden duş perdeleri yerine şiddetle önerilmektedir (Bayraktar 1989) (Resim 9h). Dönemin önemli mimarlık ve dekorasyon dergilerinden birisinde, apartman dairelerinin küçük olmasından dolayı, banyonun hem fonksiyonel hem de estetik açılardan düşünülmesi gerektiği söylenerek, dönemin 'lüks' ve büyük küvet saplantılı müteahhitleri de eleştirilerek, kullanıcılara, büyük banyo küvetleri yerine küçük oturmalı küvetler veya küçük duş kabinleri kullanmaları önerilmektedir (Özışık 1989).

80'li yılların ikinci yarısındaki dergi reklamları, banyonun, birbiri ile uyumlu elemanlardan oluşan bir bütün olarak algılanmaya başlandığını göstermektedir. Ancak, banyolarda dolap kavramı -ya yüksek maliyetli olduğundan ya da fikir olarak pek yaygın olmadığından- reklamlarda lüksün temsili olarak görülmektedir.

Sonuç olarak, 80'lerin sonuna doğru:

- banyoda bütüncül bir tasarım anlayışı yaygınlaşmaya başlamıştır.

- renkli banyolar bu dönemde zirveye ulaşmıştır.

- banyo elemanları en az bugünkü kadar çeşitlilik göstermiştir; farklı tipte banyo küvetleri, farklı tipte duş kabinleri, gömme klozet rezervuarları, çeşitli tiplerde klozetler, su tasarruflu sifon sistemleri, geleneksel ve yarım ayaklı lavabolar, renkli ve termostatlı armatürler, renkli ve/veya desenli vitrifiye elemanları ve duvar karoları gibi banyo elemanları, yerli ve yabancı markalar altında pazara sunulmuştur.

\footnotetext{
${ }^{11}$ Çalışma için, Arredamento Dekorasyon, Arredamento Mimarlık, art+décor, Betonart, Ege Mimarlık, icon Türkiye, Maison Francaise, Marie Claire Maison, Mimarlık ve Dekorasyon, Mimarlıkta Malzeme, Mimarlık, RAF, Şehir, Tasarım, XXI dergilerindeki banyo ve banyo elemanları reklamları taranmiştır.

${ }^{12}$ Türkiye'de seramik üretim geleneği, 8000 yıl öncesine, Anadolu’ya dayanır ve buna bağlı olarak günümüzde seramik sağlık gereçleri sektörü daha çok yerel firmaların hakim olduğu bir sektördür. Sektörün ilk üretimi, 1958 yılında Eczacıbaşı tarafından İstanbul'da gerçekleşmiştir, ancak sektör, gelişmeye 1980'li yıllarda başlamıștır (TC Bilim Sanayi ve Teknoloji Bakanlığı 2012). Bugün, Türkiye'de dokuzu büyük ölçekli ve 30’u orta ölçekli olmak üzere 39 üretici bulunmaktadır (TC Bilim Sanayi ve Teknoloji Bakanlığı 2012). Sektöre, Eczacıbaşı (Vitra), Kale Seramik, Çanakçılar Seramik (Creavit), Kütahya Seramik, Ece Banyo, Ege Seramik, Kalevit ve Serel firmaları liderlik etmektedir (TC Ekonomi Bakanlığı 2013 ). 17 milyonluk üretim kapasitesi ile Avrupa'nın en büyük seramik sağlık gereçleri üreticisi olan Türkiye (Turkish Ceramics Federation t.y.), üretimin \%44.3 lük payını ihraç etmektedir (TC Bilim Sanayi ve Teknoloji Bakanlığı 2012).
} 

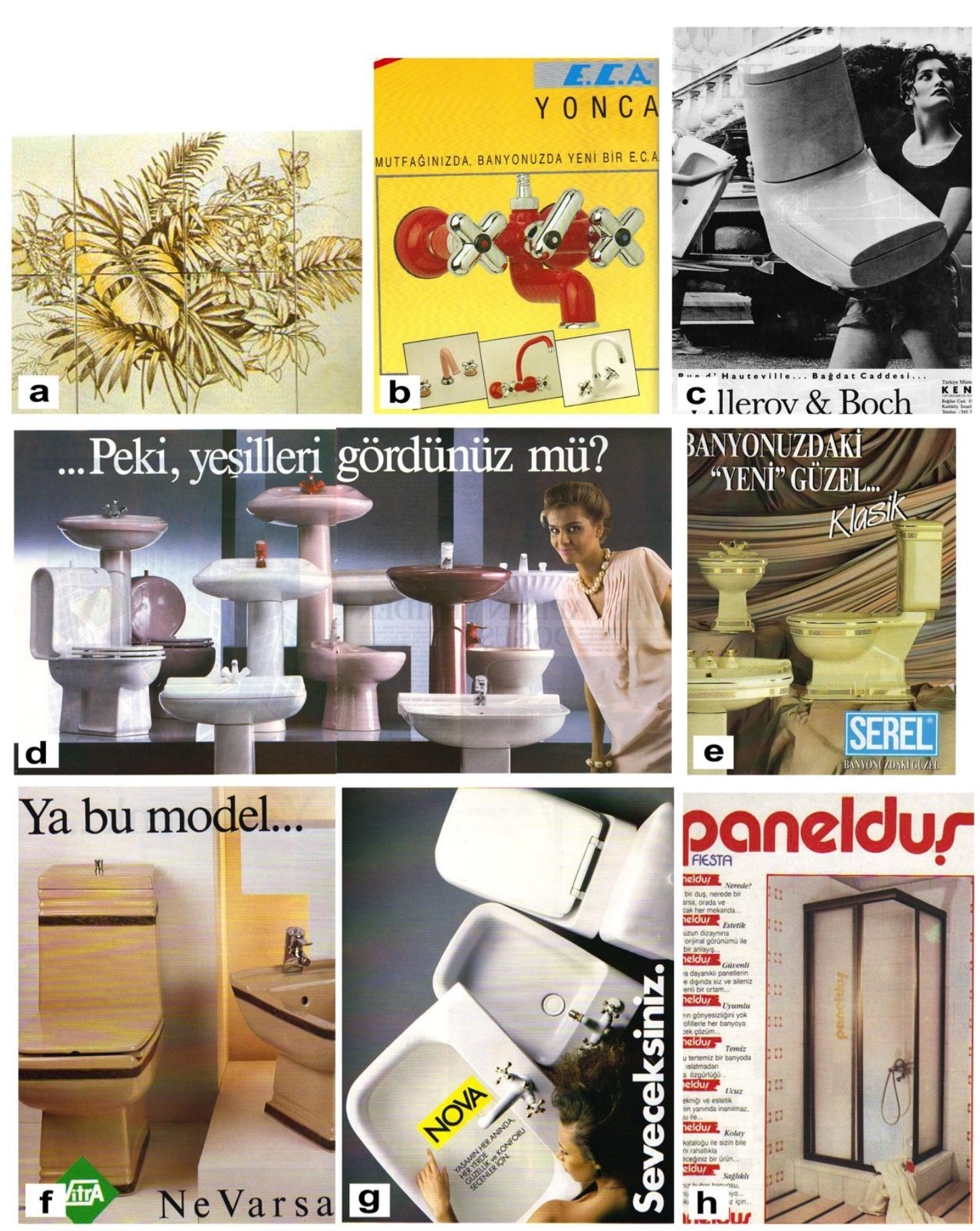

Resim 9: a) 80'lerin renkli ve desenli duvar karolarına bir örnek, Arredamento 1989, 6-7 b) ECA renkli armatür, Arredamento 1989, 5 c) Villeroy \& Boch organik formlu vitrifiye seti, Şehir, 1987, 8 d) Vitra renkli vitrifiye tasarımları, Şehir, 1987, 8 e) Serel renkli ve parlak kaplamalı vitrifiye seti, Mimarlık 1989, 237 f) Vitra renkli vitrifiye seti, Arredamento 1989, 4 g) Toprak Seramik, basit ve sade geometrik çizgiler taşıyan vitrifye seti, Arredamento 1989, 3 h) Panelduş duş kabini, Mimarlık, 1989, 233.

\section{0'lar}

90’lı yıllara ait dergi reklamları, dönemin ilk yarısının, varlığın simgesi olan ve daha çok armatürlerde ve aksesuarlarda kullanılan, altın sarısı kaplama yılları olduğunu açıkça göstermektedir (Resim 10a, 10b). Dönemin sonuna doğru ise altın sarısı sahneyi krom görünümüne bırakmıştır. Ancak, dönemin baskın renkleri sadece altın ve krom değildir; 90'larda form çeşitliliği arayışlarının yanı sıra, 80'lerde süregiden renk çeşitliliği de devam etmiştir. Dönemin reklamları çok çeşit renkte ve tipte modeller sunarken, 80’li yıllar ile karşılaştırıldığında bir fark dikkati çekmektedir; 90 'lı yıllarda çoğunlukla akrilik olmak üzere plastiğin kullanımı artmıştır. 80'li yıllarda diğer malzemelere göre kalitesiz olarak değerlendirilen plastik (Bayraktar 1989), 90'lı y1llarda istenilen renk ve formu elde etmede esneklik sağlayan bir firsat olarak lanse edilmektedir. Özellikle akrilik küvetler, yüksek 1sı yalıtımı, dayanıklılık, kolay 
temizleme ve hijyenik olma özellikleri ile reklamlarda yüceltilmektedir. Ayrıca, yine dönemin reklamlarında fark edilmektedir ki, plastiğin yaygın kullanımı, çeşitli tiplerde renkli banyo aksesuar setlerinin tasarımını da beraberinde getirmiştir. Banyoda bütüncül tasarım yaklaşımını öne çıkararak, bu plastik aksesuar setleri de, seramik vitrifiye setlerinin yanında, modern banyonun diğer bileşenleri haline gelmişlerdir (Resim 10c, 10d). Bunlara ek olarak, banyo tekstili reklamları da 90’lı yıllarda görülmeye başlamıştır (Resim 10e). Tüm bu reklamlara bakıldığında, banyo mekânının, 'yaşanacak mekân’ veya 'keyif alınacak mekân’ olarak temsil edilmeye çalışıldığı söylenebilir.

Yukarıdaki banyo elemanlarına ek olarak, neredeyse tüm bir duvarı kaplayan, geniş aynalar 90’lı yılların banyo mekânlarının moda unsurlarından biri olmuştur. Bu tip aynalar, çoğunlukla, dolapları ve tezgah altı lavabosu ile beraber görülmektedir. Tezgah altı dolap, tezgah altı lavabo ve onları tamamlayan geniş ayna grubundan oluşan bu tasarım tarzı, öncelikle kurumsal otellerde uygulandığı ve yaygın olarak tercih edildiği için üreticiler ve halk arasında 'Hilton lavabo' olarak adlandırılmaktaydı. Bu dönemin reklamlarına bakıldığında, 90’larda toplumun belli bir kesimi tarafından hemen kabul gören Hilton lavabonun, bir başka varlık ve prestij sembolü olarak 90’lı yıllara damgasını vurduğu görülmektedir (Resim 10f, 10g). Dönemin ikinci yarısında ise Hilton lavaboya bir alternatif olarak sunulan etajerli lavabo tasarımları piyasaya sürülmüştür (Resim 10h).

90’lı yıllar, ayrıca, Türkiye'de uzun süreli su kesintilerinin yaşandığı ve bu döneme kadar üzerinde pek durulmamış olan çevre sorunlarına dikkatin çekildiği yıllar olmuştur. Bu sorunların farkında olan firmalar su tasarruflu ürünler tasarlarken bu tarz ürünlerin de reklamları artmıştır. Bazı firmalar, suyun en çok kullanıldığı elemanlardan biri olan klozet rezervuarlarının su tüketimini dokuz litreden altı litreye indirecek sistemler tasarlamıştır. Bu tip rezervuar modellerin yanı sıra, kir tutmayan, 'sıfır pürüz' seramik yüzeyleri ile hem su hem de deterjan tüketimini azaltacağı iddia edilen ürünler de dikkat çekici reklamlarla piyasaya sürülmüştür (Resim 10i).
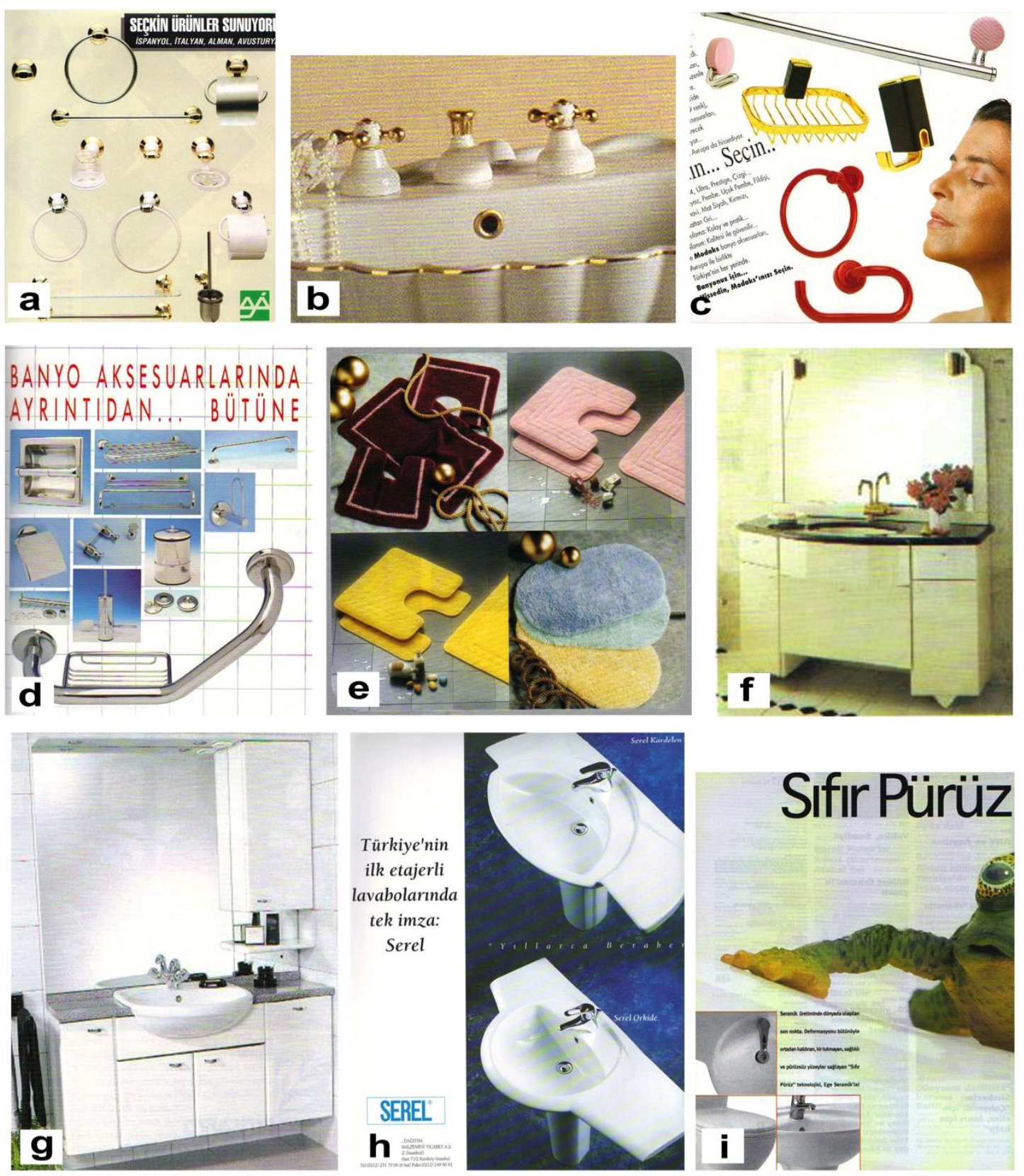

U4J I 
Resim 10: a) Altın ve krom görünümlü ithal aksesuarlar, Arredamento, 1991, 30 b) Altın renk şeritli Serel vitrifiye ve armatür, Mimarlık, 1990, 240 c) Modaks renkli aksesuarlar, Arredamento, 1991, 30 d) Krom görünümlü Armim aksesuarlar, Arredamento, 1994, 57 e) Zucchi banyo tekstil setleri, Arredamento, 1991, 30 f) Hilton lavabo örneği, Arredamento, 1990, 17 g) Alba modüler banyo dolapları ve Hilton lavabo örneği, Arredamento, 1994, 56 h) Türkiye'nin ilk etajerli lavabo tasarımları, Ege Mimarlık, 1997, 22 i) Ege Seramik 'Sıfir Pürüz' vitrifiye elemanları, Arredamento, 1997, 94.

90'lı yıllarda dış ticaretin serbest hale gelmesinin etkileri yabancı üreticilerin reklamlarındaki artış ile de hissedilmektedir. Hem yerli hem de yabancı üreticiler tarafindan üretilen duş kabinleri (bir başka deyişle 'modern duş') yaygınlaşmaya başlarken, bu artış ilginç bir biçimde, su jetli küvet modasını da tetiklemiştir (Resim 11a, 11b). Aslında, bu on yılın dergi reklamlarında sergilenen duş kabini ve masajlı küvet arasındaki çekişme, sadece bu ürünler arasında değil, hızlı bir duş ile uzun rahatlatıcı bir banyo deneyimi arasında, yani bunlarla ilişkilenen hayat tarzları arasında gerçekleşmektedir. Bu rekabet ile ilişkili olarak, bazı reklamlar banyoyu rahatlama ve kendini yenileme mekânı olarak sunmaktadırlar. Bu yaklaşım, ahşap dolapları, büyük tezgahları, geniş aynaları, canlı bitkileri ve çeşitli dekoratif aksesuarlarıyla, banyoyu, sanki evin bir odasıymış gibi sunan reklamlarda da fark edilmektedir. Banyo mekânında söz konusu 'oda' atmosferinin yaratılmasında etajerli lavabo ve tezgahlı lavabo tasarımlarının sağladığı ek düzlemsel yüzeylerin fonksiyonu önemlidir. Ayrıca, banyolarda bu 'oda' konforunu sağlamada etkili olan, dönemin çeşitli teknolojilerinin gelişmesi ile hayata geçen, dayanıklı seramik derz dolguları, etkin ve uzun ömürlü tesisat sistemleri, çeşitli tiplerde su 1sıtıcıları, uzun ömürlü ve çizilmeyen tezgah malzemeleri ve suya dayanıklı dolap kaplamaları gibi ürünlerin de küçümsenmemesi gerekmektedir (Resim 11c, 11d, 11e, 11f).

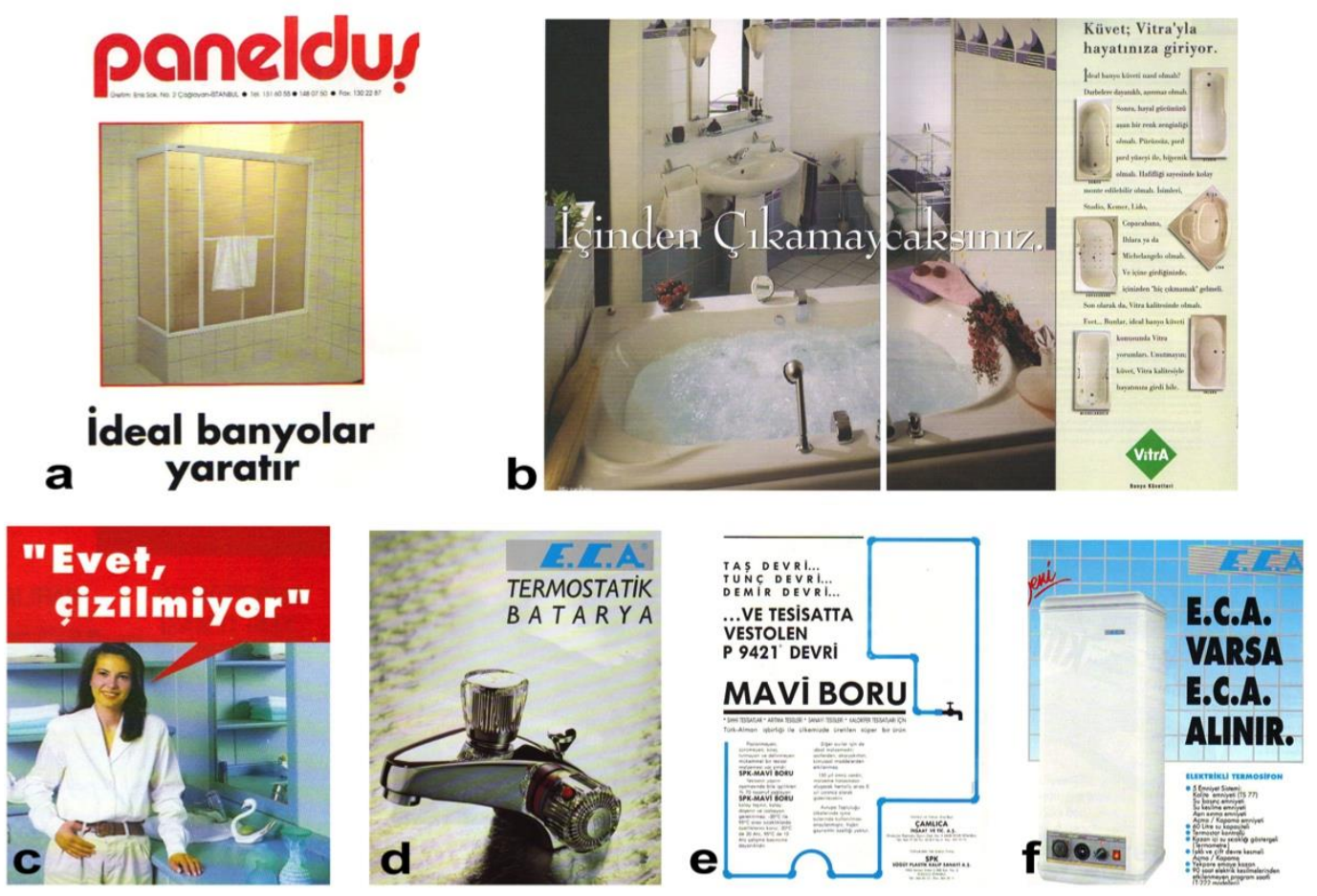

Resim 11: a) Panelduş modern duş kabini, Arredamento, 1990, 17 b) Vitra akrilik küvet modelleri, Ege Mimarlik, 1996, 19 c) Demsan çizilmeye dayanıklı banyo tezgahı, Arredamento, 1993, 52 d) ECA termostatik batarya, Tasarım, 1990, 9 e) Mavi Boru dayanıklı tesisat boru sistemleri, Arredamento, 1991, 22 f) ECA su 1sitıcis1, Arredamento, 1992, 37.

Ali Cengizkan'ın, 20. yüzyılda modern banyonun üstüne yeterince düşünmediğimizi, onu bir şablon gibi çoğaltma ve ona yabancılaşma sürecimizi aktardığı 'Yabancılaşma Nesnesi Olarak Banyo: Modernizm, Tüketim Toplumu ve Banyo Kültürü' (2002) isimli çalışmasına göre, 90’lı yıllar tüketimin ve indirgeyici piyasanın baskın olduğu yıllar olmuştur; gelişen reklam teknikleri, hızlanan sermaye girişi ve artan gelir düzeyleri ile banyo mekânının kendisi “tüketim nesnesi yutan tüketim nesnesi” haline gelmiştir (s. 151). Cengizkan (2002), o dönemlerde, banyo ve mutfak firmalarının ve dergilerinin, birbirinden farklı bir çok iyi fikir sunuyormuş gibi görünmelerine rağmen, aslında temelde, aynı kalıptan çıkan, şablon bir banyo tasarımını hızla çoğaltmalarını eleştirir. Daha önce de belirtildiği gibi, bu yıllarda, çevreye duyarlılık öne çıkmış ve buna dayanarak, piyasada, banyolarda enerji ve su tasarrufu sağlayan yeni banyo elemanları çoğalmıştır. Bu dönem, Cengizkan’a göre (2002) kullanıcılara banyolarını bu yeni elemanlarla yenileyerek yeni yüzyıla hazırlamaları telkini verilen ve onları daha fazla tüketime iten bir dönemdir, ki sırf bu yenileme bile yüklü 
bir maliyet, mekânsal değerlerin kaybı ve hesaplanmayan su ve enerji harcanması demektir. Öte yandan, 1990’ların başında, 'yeni', 'farklı' ve 'gelişmiş' söylemleri ile beraber banyo vitrifiye malzemeleri ve aksesuarları değişmeye başlar. Dönemin sonuna doğru açıkça görülür ki bu değişiklik sadece banyodaki ürünler ile ilgili değildir; Cengizkan’ın (2002) deyimiyle, banyo değişmiş, banyo odasının kendisi 'ürün'ün kendisi olmuş ve bir özlemin nesnesi haline gelmiştir ve bu değişim ve yaratılan bu özlem de, dönem boyunca reklamlara bakıldığında kolaylıkla takip edilebilmektedir.

Sonuç olarak, 90’lı yılları özetlemek için yine Cengizkan'a (2002), Türkiye'de modern banyonun hikayesini değerlendirdiği çalışmasına dönmek faydalı olacaktır. Cengizkan (2002) 'modern' banyonun, 'modern' apartman blokları ve daireleri gibi bir yabancılaşma nesnesi olarak ortaya çıktığını söyler. 20. yüzyıl boyunca, Türkiye’deki kullanıcılara, bu banyo modelini, sanki bir şablonmuş gibi, seri üretim bir nesne olarak sunulduğunu tartışan Cengizkan (2002), böylece, konutun, dolayısı ile banyonun, kimliğimizin yansıyacağı veya kendimizi yenileyip yeniden üreteceğimiz bir mekân olması gerekirken, bir tüketim nesnesi haline geldiğini iddia eder. Modern banyonun bu evrimleşemeyen evrimini eleştirir ve bu evrimin geleneksel çözümler ile başladığını ancak 'zengin' elemanlarla doldurulan, 20. yüzyılın 'yoksul' banyo şablonu ile bittiğini söyler.

\section{0'ler}

2000-2012 yılları arasındaki reklamlara bakıldığında, modern banyonun bu dönemdeki en belirgin özelliği temsil ve pazarlanma biçimidir. Değişen banyo kavramının, uyumlu vitrifiye setlerinden ve duş kabinlerinden, 'tematik banyo’ya veya ‘yaşayan mekânlar’a doğru dönüştüğü dönemin reklamlarında açıkça görülmektedir (Resim 12). 90’lı yılların sonuna doğru başlayan bu geçiş, 21. yüzyılın banyo eğilimlerini belirlemiştir; bu eğilimlerden bazıları, banyoların kullanıcının yaşam tarzını yansıtması, banyoda sağlık, huzur, konfor ve keyif kavramlarının yüceltilmesi ve banyonun boş vakit geçirilebilecek bir mekân olarak tasarlanması olmuştur. 21. yüzyılın yorucu, stresli ve yoğun gündelik hayatına dair çare arayışları gibi görünen bu temalar, neticede 'evde zindelik' (wellness at home) kavramının yaygınlaşmasına katkı sağlamıştır. Bu kavramlarla da ilişkili olarak, bu dönem reklamların tarzları, banyoyu bütüncül bir mekân olarak düşünmenin, tasarlamanın ve pazarlamanın ne kadar önemli olduğunun anlaşıldığını göstermektedir. Bu değişim, reklamlarda kullanılan terminolojide de kendisini göstermektedir; mesela, 80'li yıllarda kullanılan 'banyo dolapları' ve 'banyo aksesuarları' terimleri, 90’larda 'banyo mobilyası'na, 2000'lerde ise 'banyo çözümleri’ne dönüşmüştür.
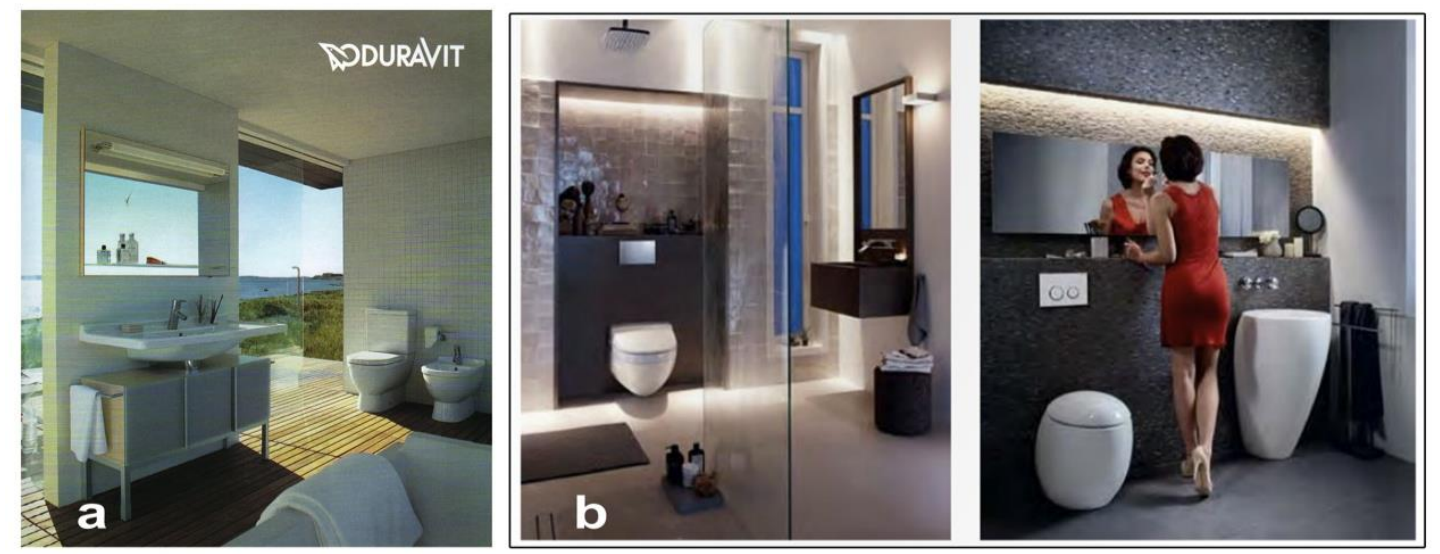

Resim 12: 2000'li y1llara ait tematik banyo reklamlar1; a) Duravit banyo, art+décor, 2004, 139 b) Geberit banyo, XXI, 2012, Mart.

21. yüzyıl banyo reklamlarında sergilenen banyoların geçmiş dönemlerden bir farkı da, gittikçe kalabalıklaşan şehirlerdeki küçük apartman dairelerine özel, küçük hacimler için tasarlanmış seçeneklerin olmasıdır (Resim 13a, 13b). Yine nüfus artı̧ı ile ilişkili olarak, reklamlarda vurgulanan su tasarrufu ile ilgili hassasiyet ve çevreci yaklaşımlar da, 90'lı yıllara göre giderek artmıştır (Resim 13c). 20. yüzyıl banyo reklamlarında görünmeyen, bu yüzyıla ait başka bir hassasiyet de banyoların engelliler ve yaşlılar için tasarlanmasıdır (Resim 13d). Bunlara ek olarak, el teması gerektirmeyen temizliğin ve genel ve kişisel hijyenin önemi, bir çok firmanın reklamlarında, uygun ürün ve teknolojilerle vurgulanmaktadır (Resim 13e). 

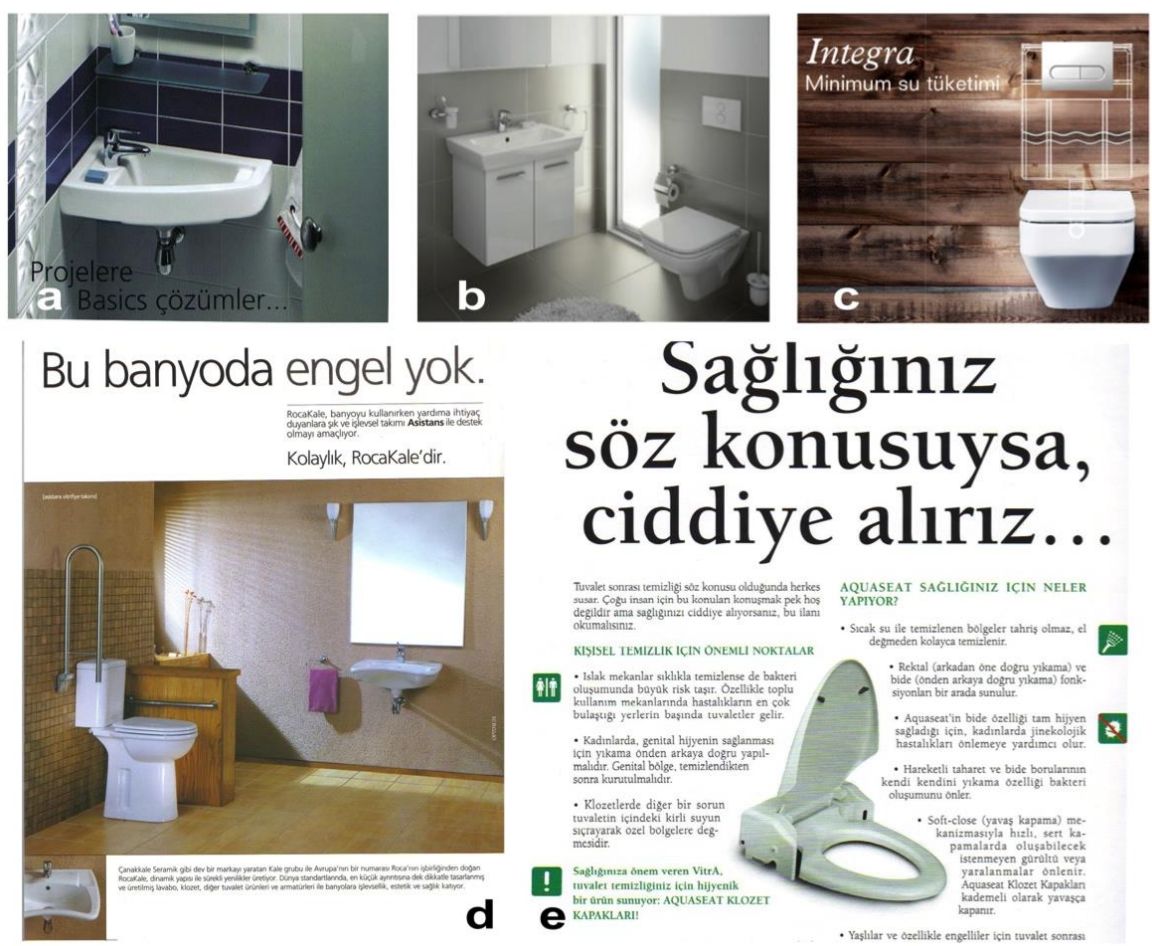

Resim 13: a) Dar alanlar için tasarlanmış küçük boyutlu RocaKale lavabo, Maison Francaise, 2008, 152 b) Kısıtlı alanlarda da konfor sağlayan Vitra S50 vitrifiye seti ve banyo mobilyası, XXI, 2011, Eylül c) Çevresel sorunlara duyarlı, su tasarrufu sağlayan Kale rezervuar, Kale e-bülten, 2012, Aralık. d) RocaKale engellilere özel banyo tasarımı, Betonart 2004, Bahar e) Kişisel sağlığı vurgulayan Vitra hijyenik klozet kapağı, art+décor, 2005.

21. yüzyılda banyoda renk kullanımına dair, yaygın kullanılan renklerin ve tonların yanı sıra, özellikle dolap kapaklarında ve duvar karolarında, parlak tonlar gibi sıra dışı renk tonlarının reklamlarda öne çıktığı söylenebilir (Resim 14b, 14c). Form açısından ise, bu dönemin baskın tarzı sade ve geometrik çizgilerden oluşmaktadır, ancak bugün piyasada çeşitli zevklere uygun çok çeşitli tasarım çizgilerini de görmek mümkündür. Özellikle ilk 10 yılın sonlarına doğru kullanıcılara nerdeyse mümkün olan her tasarım seçeneği sunulmaya başlanmıştır, mesela bir vitrifiye setinin içindeki bir lavabo, kullanıcının tercihine bağlı olarak çeşitli boyut ve dolap opsiyonları ile ayaklı, yarım ayaklı veya duvara asılı olarak temin edilebilmektedir. Bu yüzyılın reklamlarına baktığımızda, vitrifiye elemanları arasında en çok öne çıkan tasarımlar, çanak tipi ve tezgah üstü lavabolar ve az yer kaplayan, gömme rezervuarlı, asma klozet tasarımlarıdır (Resim 14a, 14b, 14c). Ayrıca, reklamlarda, banyo dolaplarının kullanımının da devam ettiği, hatta, dolapların aile bireylerinin farklı ihtiyaçlarına göre tasarlandığı görülmektedir.
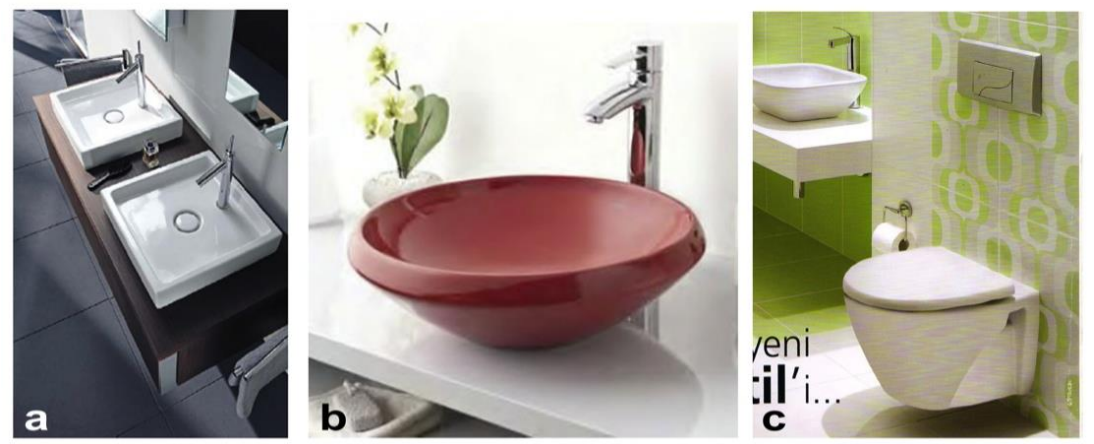

Resim 14: a) Duravit tezgah üstü lavabo, Raf, 2011, 34 b) Creavit renkli çanak lavabo, XXI, 2012, Mart c) RocaKale asma klozet, gömme rezervuar, çanak lavabo, Marie Claire Maison Türkiye, 2008, 40.

Bu dönemde, banyo tasarımlarında devam eden bir başka unsur da, 1990'lardan beri revaçta olan Hilton lavabo kavramıdır. Bir prestij sembolü olarak ortaya çıkmış olan Hilton lavabo tipi, günümüzde orta ve üst-orta sınıf konut-site projeleri, tadilat yapılan eski apartman daireleri, orta kaliteden yüksek kaliteye kadar eski ve yeni kiralık apartman 
daireleri gibi farklı tip konutların banyolarında farklı şekillerde kullanılmaktadır (Resim 15). Bu ortak beğeninin olası sebepleri şunlar olabilir; (1) geniş bir kullanıcı kitlesi tarafından beğenilen, genel kabul görmüş bir tasarım çözümü olması, (2) maliyet avantajı olması, (3) banyo işleri yapan herhangi bir marangoz veya mobilya ustası tarafından kolaylıkla üretilebilir olması, (4) piyasadaki diğer çözümlerle karşılaştırıldığında, kullanıcının tercihlerine ve mekânın ebatlarına göre özel olarak yapılabildiğinden, karar verme aşamasında kullanıcıyı kısıtlamayan ve ona zorluk çıkarmayan bir çözüm olması. Bunlara ek olarak, banyo hacimleri 21. yüzyılda da çoğunlukla belli bir büyüklüğü geçmediği için, Hilton lavabonun bir başka avantajı da banyoyu daha büyük gösteren geniş aynası olabilir. 21. yüzyıl banyo reklamlarında sıkça görünen çerçevesiz, tamamen şeffaf, cam duş kabinleri de banyo mekânını olduğundan büyük göstermek için başvurulabilecek bir başka yöntem olarak değerlendirilebilirken, öte yandan bu tip duş kabinleri, mahremiyet kavramındaki değişikliğin bir göstergesi olarak veya kabinin içindeki tasarım nesnelerini de sergilemeye yarayan bir unsur olarak da algilanabilir.
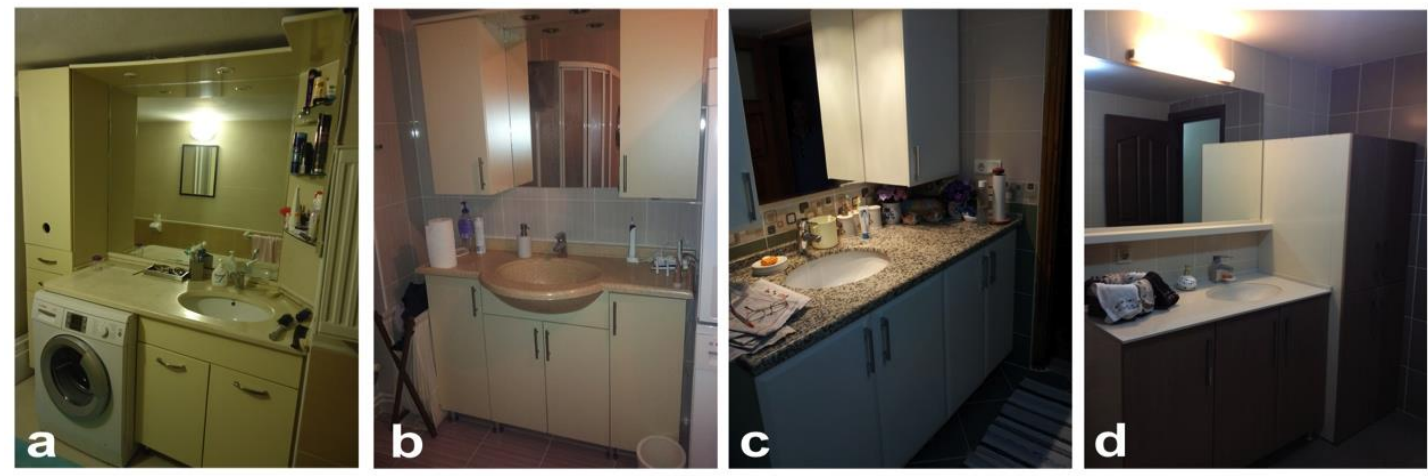

Resim 15: Günümüzde, çeşitli konut tiplerinde kullanılan Hilton lavabo türevleri, a) 2008 yılında banyo tadilatı yapılan kiralık bir apartman dairesi b) 2009 yılında banyo tadilatı yapılan 43 yıllık bir apartman dairesi c) 2009 yılında banyo tadilatı yapılan 26 yıllık bir apartman dairesi d) 2011 yılında kullanıma açılan üst-orta sınıf bir konut sitesinin banyosu (Fotoğraflar yazar tarafindan çekilmiştir, 2012).

Yüzyılımızın tasarım eğiliminin de bir parçası olan, heykelsi vitrifiye tasarımlarının büyük markalar tarafından zaman zaman piyasaya sürüldüğü ve bu tasarımların reklamlarının da, banyodan çok, sanki heykel müzesinden bir kare gibi oldukları dikkat çekmektedir (Resim 16). Bir ürün dergisi bu tarz ürünlerin tanıtımını yaparken, banyo heykelleri başlığı altında, ihtişam ve göz kamaştırıcı bir çekicilik getiren lavabo heykelleri ile artık banyoların bir showroom'a döndüğünü belirtmektedir (Duravit - Banyo Heykelleri 2005)
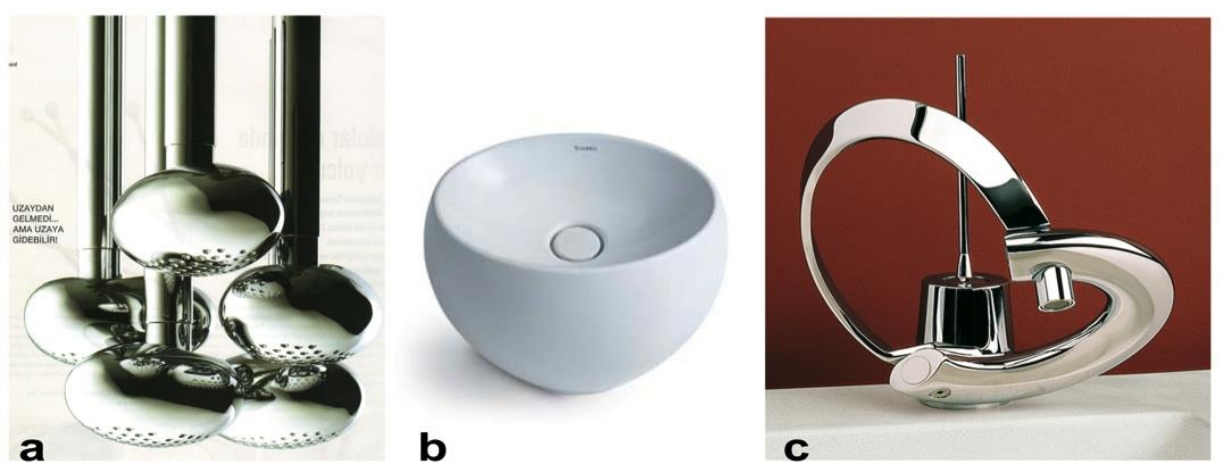

Resim 16: Heykelimsi tasarımlar; a) Rose Lovegrove tarafından tasarlanan Artema armatür, Maison Francaise, 2006, 132 b) Sieger Design tarafindan tasarlanan Duravit lavabo, Raf, 2005, Kasım c) Paolo e Francesca armatür, Maison Francaise, 2003, 96.

Günümüzün göze çarpan tasarım ve pazarlama yaklaşımlarından bir diğeri de büyük firmaların, tanınmış yerli veya yabancı endüstriyel tasarımcılar ve mimarlarla çalışarak özel bir tasarım kavramı oluşturmasıdır. 20. yüzyılda büyük firmalar, firma dışından profesyonel 'dizayncılar' ile çalıştıklarında, ürünü piyasaya sürerken, tasarımcısının ismini de beraberinde kullanmayı gerek görmezken (Tarim ve Öneş 1990), günümüzün ünlü markaları tanınmış bir endüstriyel tasarımcı veya mimarla çalıştığında, ürünün reklamlarında tasarımcının ismine özellikle vurgu yapmaktadırlar (Resim 17). 


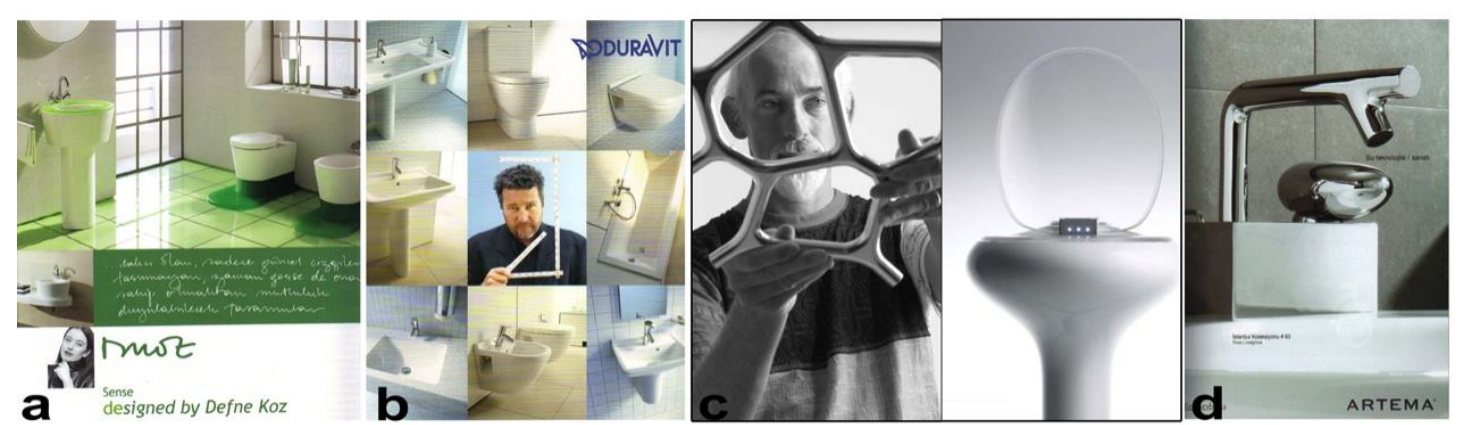

Resim 17: 21. yüzyılda firmalar tanınmış tasarımcı veya mimarlarla çalışmaya başladılar ve bunu da reklamlarında vurguladılar: a) Vitra Sense, Defne Koz, art+décor, 2003, 127 b) Duravit, Philippe Starck, Arredamento, 2004, Nisan c) Vitra İstanbul Koleksiyonu, Ross Lovegrove, Raf, 2006, Mayıs d) Artema İstanbul Koleksiyonu, Ross Lovegrove, 2006, Arredamento, Haziran.

Son olarak, sadece 21. yüzyılı değil, Türkiye'de modern banyonun geride biraktığı on yılları da beraber değerlendirirsek, tüm bu yıllar boyunca, sürekli reklamlarda boy gösteren bide analiz edilmelidir. Bide, 80’lerin sonuna doğru, Türkiye'de gündelik hayat pratiklerinde artık kendine yer bulamamış, tadilat yapılan banyolarda geçmişten kalıntı olarak görülen, sökülen ve yenilenmeyen bir ürün haline gelmiştir. Ancak, şaşırtıcı bir biçimde, geçmişten bugüne, vitrifiye setleri sürekli 3 parçalı set olarak tasarlanmıştır ve reklamlarda ve kataloglarda bu şekilde sergilenmiştir. 1980-2012 yılları arasındaki reklamlara bakıldığında, bidenin, gündelik hayattaki yerinden bağımsız olarak, yeni bir model tasarlanırken, setin bir tamamlayıcı elemanı gibi düşünüldüğü ve reklamlarda da sunulduğu görülmektedir (Resim 18).
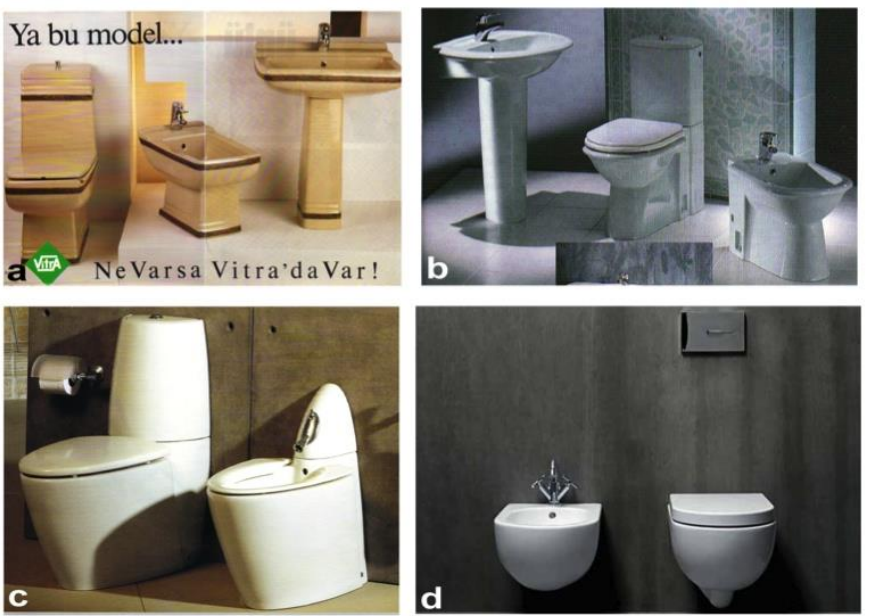

Resim 18: Farklı dönemlerden, bidenin de bulunduğu vitrifiye seti reklamları, bidenin gündelik hayattaki yerinden bağımsız olarak, yeni bir model tasarlanırken her zaman bidenin de düşünüldüğünü göstermektedir. a) Vitra, Arredamento, 1989,4 b) Serel, Arredamento, 1995, 68 c) RocaKale, art+décor, 2003, 127 d) Kale, Raf, $2011,31$.

\section{Sonuç Yerine}

Gündelik hayat sadece rutinlerin, törenlerin ve geleneklerin değil, insanın çevresindeki 'şey'lerin de bir bütünüdür. "İnsanlar ve insan yapımı şeyler, özellikle günlük, alışılagelmiş eylemler sırasında, birbirlerini sürekli oluştururlar" (Hofstede 2001, 110), dönüştürürler ve tamamlarlar. Bu nedenle insan, çevresindeki şeyleri yani ürünleri kabul eder ve içselleştirir, aksi durumda ise anlamaz, dışlar ve hatta nefret eder. Rutin eylemler eşliğinde, ürünleri gündelik hayatına nasıl dahil edeceğine, nasıl kullanacağına dair kararlar verir. Ancak Türkiye'de, modern banyo ve ona ait maddi kültür, gelenekler ile alışılagelmiş gündelik yaşam rutinlerinden bağımsız olarak 'Batılılaşarak modernleşme ideali' çerçevesinde dışarıdan ihraç edilmiştir. Mimari ölçekte standart plan şemaları, nesne ölçeğinde standart ürün tipleri bu idealin temel belirleyici unsurları olmuştur. Modernleşmenin sorun çözme, mekânı etkin kullanma ve geniş bir orta sınıf yaratma ideali, sıkıştırılmış hücre tipi banyo çözümlerinde karşılığını bulmuştur. Üst ve üst-orta sınıfın kendini ayrıştırma eğilimi ise genişletilmiş, gösterişli nesnelerle donatılmış, banyonun bir yaşama mekânına dönüştüğü bir ideal, adeta bir hayal olarak bedenleşmiştir. Tüketim kültürünün uzantısında şekillenen ideal banyo ya da modern banyo 
reklam imgeleri, banyo mekânı üzerinden modernleşme hayalinin kitleleri besleyen belki de en açık tezahürleri olmuştur. Türkiye'ye de modern banyo, modernleşme idealinin bir gerekliliği ve modern olmanın bir sembolü olarak gelmiştir. Bu idealin baskınlığı, gelenek ve geçmişten gelen temizlenmeye yönelik alışkanlıklar ile yeni ürünler arasındaki yabancılık durumunu göz ardı etmeyi gerektirmiştir. Ancak modern banyonun Türkiye'deki kullanıcısı, bu yeni ürünleri ve eylemleri çeşitli yollarla içselleştirmeye çalışmıştır. Bu içselleştirme, yabancı olan ürüne yeni bir işlev ekleyerek veya onun işlevini değiştirerek (Burkhart 2006) yani klozete taharet musluğu ekleyerek veya küvet için yeni kullanım biçimleri icat ederek gerçekleşmiştir. Aslında, yapılan bu bilinçli değişimler, ürünün potansiyelini de ortaya çıkartmakta ve tasarımcılar için de yeni fikir geliştirme anlamında birer ilham kaynağı olmaktadır (Parsons 2009) Nejat Ersin'in, küvetin içinde kova ve tabure ile yıkanılması pratiğinden yola çıkarak tasarladığı oturmalı küvet (Gürel 2008) bunun en iyi örneklerinden olmuştur. Bu örnek ayrıca, tasarımın ve kültürün sürekli etkileşim halinde olduğunu, tasarımın kültürü değiştirirken kültürün de tasarımı biçimlendirdiğini göstermektedir (Moalosi vd. 2010). Bir kültüre ait gelenekler, değerler ve alışkanlıklar, o kültüre özel ürün tasarımlarını gerekli kılabilir ve o kültürel ihtiyaçların ve durumların tanımladığı bu ürünler, sadece o kültürel bağlamda anlamlı hale gelirler.

Literatüre bakıldığında, banyonun, çoğunlukla tarihsel, mimari ve teknik çalışmaların konusu olduğu görülmektedir. Literatürde, banyonun yanı sıra, tuvaletin tarihi, toplumsal ve kültürel evrimi ve teknik özellikleri ile ilgili de bir çok çalışma bulunmaktadır. Ayrıca, çoklukla sosyoloji alanında olmak üzere, hijyen ve temizliğin ölçünleri ve ideallerinin tarihi, toplumsal-kültürel evrimi ile ilgili kapsamlı çalışmalar yapılmıştır. Bu çalışma, Türkiye’de modern banyonun toplumsal ve kültürel değişimi ile ilgili az sayıdaki çalışmaları da aktararak, modern banyonun ve onun oluşturduğu maddi kültürün ilk ortaya çıkışından günümüze kadar geçirdiği değişimi dergi reklamlarının görselleri eşliğinde değerlendirmeye çalışmıştır. Bu görseller kitlelerin modern olma hayalini besleyen temel imgeler ve tetikleyiciler olarak ele alınmıştır. Bu çalışma, banyo ve elemanlarının her zaman ekonomik ve ticari değişimlerden bire bir etkilendiğini, banyo mekânının zengin bir tasarım alanı olduğunu, ancak modern banyonun ilk ortaya çıkışından bugüne teknolojik ilerlemeler dişında, temelde, çok da değişmediğini göstermiştir. Hatta, modern banyonun, modernleşmenin kültürel farklılıklara karşın aynılaştırıcı ve standartlaştırıcı gücünün tipik bir örneği olduğu söylenebilir. Kültürel farklılıkların bile modern banyonun ne mimari ölçekteki plan şemalarını ne de standart ürün tiplerini pek de etkilemediği, ideal reklam imgeleri eşliğinde bu tiplerin sadece renk ve malzeme farklılıkları olarak çeşitlenerek yaygınlaştığını ve yeni ürün tasarımları algısını ürettiği gözlemlenmiştir.

\section{KAYNAKÇA}

Bayraktar, E. (1989). Romantizm, güzellik ve sağlık: Hepsi birarada olmalı. Arredamento Dekorasyon, Nisan, s. 108109.

Bektaş, C. (1998). Yiğit yattığ1 yerden belli olur. Bak bak desinler (s. 16-18). İstanbul: Evrensel Basım Yayın.

Bozdoğan, S. (2002). Modernizm ve ulusun inşasl: erken Cumhuriyet Türkiyesi'nde mimari kültür. İstanbul: Metis Yayınları.

Burkhart, A. (2006). Object lessons: Thinking about material culture. Art Education, 59(2), 33-39.

Cengizkan, A. (2002). Yabancılaşma nesnesi olarak banyo: modernizm, tüketim toplumu ve banyo kültürü. Modernin saati. İstanbul: Mimarlar Derneği.

Duravit - Banyo Heykelleri. (2005). Raf, Kasım, s. 63.

Giedion, S. (1955). Mechanization takes command. New York: Oxford University Press.

Glassberg, D. (1979). The design of reform: The public bath movement in America. American Studies, XX(2), s. 5-21.

Gürel, M. Ö. (2008). Bathroom as a modern space. The Journal of Architecture, 13(3), s. 215-233.

Hembry, P. M. (1990). The English spa 1560-1815: A social history. London: Athlone Press.

Hofstede, G. (2001). Culture's consequences: Comparing values, behaviors, institutions and organizations across nations (2nd ed.). Thousands Oaks: Sage.

Kira, A. (1966). The bathroom, criteria for design. Ithaca, New York: Cornell University, Center for Housing and Environmental Studies.

Loos, A. (1898). Plumbers. İçinde: Lahiji N. ve Friedman D. S. der. Plumbing: Sounding modern architecture. New York: Princeton Architectural.

Lupton, E. ve Miller, J. A. (1992). The bathroom, the kitchen, and the aesthetics of waste: A process of elimination. New York: Princeton Architectural Press.

Moalosi, R., Popovic, V. ve Hickling-Hudson, A. (2010). Culture-Orientated Product Design. International Journal of Technology and Design Education, 20(2), 175-190.

Özışık, M. (1989). Peki ama ciddiyet nerede başlar? Arredamento Dekorasyon, s. 120-121.

Parsons, T. (2009). Thinking: Objects. Lausanne, Switzerland AVA Publishing.

Rybczynski, W. (1987). Home: A short history of an idea. New York: Penguin Books.

Shove, E. (2003). Comfort, cleanliness and convenience : the social organization of normality. New York, NY, USA: Berg Publishers. 
T.C. Bilim Sanayi ve Teknoloji Bakanlığı (2012). Türkiye seramik sektörü strateji belgesi ve eylem planı 2012-2016. Erişim yeri: http://www.sanayi.gov.tr/Files/Documents/turkiye-seramik-sektoru-s-27022013155310.pdf [Erişim tarihi: 24 Temmuz 2013].

T.C. Ekonomi Bakanlığg (2013). Cam ve Seramik İşaat Malzemeleri Sektörü Sektör Raporları. Erişim yeri: http://www.ibp.gov.tr/pg/sektorpdf/sanayi/cam_seramik.pdf [Erişim tarihi: 24 Temmuz 2013].

Tarim, S. ve Öneş, H. (1990). Engin Bayraktar: "Tüketici artık çok bilinçli" (Engin Bayraktar ile görüşme). Arredamento Dekorasyon Banyo'91, s. 104-107.

Tasarımcı Gözüyle (1990). (Müçteba Kundul ile görüşme). Arredamento Dekorasyon Banyo'91, s. 164-167.

Turkish Ceramics Federation (t.y.). Global position. Erişim yeri: http://www.serfed.com/eng/content.php?content_id=333 [Erişim tarihi: 24 Temmuz 2013].

Vigarello, G. (1988). Concepts of cleanliness: Changing attitudes in France since the Middle Ages (J. Birrell, Trans.). New York: Cambridge University Press.

Winkler, G. C. ve Fisher, C. E. (1989). The well-appointed bath: Authentic plans and fixtures from the 1900s. Washington, D.C.: Preservation Press.

Wright, L. (1960). Clean and decent: the fascinating history of the bathroom \& the water closet. London: Routledge \& Kegan Paul.

Yavuz, Y. ve Özkan, S. (2005). Finding a national idiom: The first national style. İçinde: Holod R., Evin A. ve Özkan S. der. Modern Turkish architecture (2. bask1). Ankara: Chamber of Architects of Turkey. 